\title{
Glycerol steam reforming with low steam/glycerol ratio in a two-zone fluidized bed reactor
}

Miriam Yus, Jaime Soler, Javier Herguido, Miguel Menéndez *

Catalysis, Molecular Separations and Reactor Engineering Group (CREG), Aragon

Institute of Engineering Research (I3A), Universidad de Zaragoza, Mariano Esquillor s/n, 50018 Zaragoza (Spain)

* Corresponding author e-mail: Miguel.menendez@unizar.es

Keywords: Glycerol reforming, two-zone fluidized bed reactor, process intensification, deactivation and regeneration

\begin{abstract}
The production of hydrogen from glycerol steam reforming has been studied in several reactors. In conventional reactors the catalyst is deactivated by coke: in fixed bed reactors plugging was observed if a low steam/glycerol ratio was employed, while in fluidized bed reactors it was possible to operate for a longer time-on-stream. The use of a two-zone fluidized bed reactor is studied in this work, as a method to counteract the problem of catalyst deactivation by coke. The glycerol reforming takes place in the upper part of this reactor while the catalyst is simultaneously regenerated in the lower part, where a stream of a regenerating gas is introduced. It has been found that $\mathrm{CO}_{2}, \mathrm{O}_{2}$ or $\mathrm{H}_{2} \mathrm{O}$ can act as regenerating gas in a two-zone-fluidized bed reactor, allowing steady state operation at a water:glycerol molar ratio as low as 1.25 . The effect of the operating conditions has been studied and the yield to the main products was compared with the calculated values assuming thermodynamic equilibrium.
\end{abstract}




\section{Introduction}

Glycerol is obtained as a by-product from the manufacture of biodiesel, representing approximately $10 \mathrm{wt} \%$ of the production. The large increase in biodiesel production worldwide in recent decades [1] has caused an oversupply of glycerol which the market has not been able to absorb. The price of crude glycerol has dropped as low as 50\$/t [2]. This situation provides the motivation to find new uses. Although glycerol is already employed in many applications, the large amount produced as a byproduct of biodiesel (c.a. 3 million tons of glycerol per year) requires a use that can absorb this gigantic production, which is not the case for high value chemicals or health care products. One possibility is hydrogen production. Hydrogen is employed in very large quantities in many applications, and syngas (the mixture of $\mathrm{CO}$ and $\mathrm{H}_{2}$ ) can be transformed by several known techniques (e.g. methanol synthesis or the Fischer Tropsch process) into liquid fuels, suitable for transportation.

Given this situation, it is not surprising that a growing number of researchers have embarked on the study of the glycerol reforming process, i.e. the production of hydrogen or syngas from the reaction of glycerol with water, according to the reaction:

$$
\mathrm{C}_{3} \mathrm{H}_{8} \mathrm{O}_{3}+3 \mathrm{H}_{2} \mathrm{O} \rightarrow 3 \mathrm{CO}_{2}+7 \mathrm{H}_{2}
$$

The above reaction is produced simultaneously with several others, as shown in table 1. In fact, it is a combination of several elemental steps. This process can be considered analogous to the steam reforming of methane, widely employed in the industry to produce hydrogen, but using a renewable fuel.

Table 1 . Most important secondary reactions occurring during glycerol steam reforming $[3,4,5]$

\begin{tabular}{|c|c|}
\hline Reaction & \\
\hline $\mathrm{C}_{3} \mathrm{H}_{8} \mathrm{O}_{3}+2 \mathrm{H}_{2}$ & $\leftrightarrow 2 \mathrm{CH}_{4}+\mathrm{CO}+2 \mathrm{H}_{2} \mathrm{O}$ \\
\hline $2 \mathrm{C}_{3} \mathrm{H}_{8} \mathrm{O}_{3}+\mathrm{H}_{2}$ & $\leftrightarrow 3 \mathrm{CH}_{4}+3 \mathrm{CO}+3 \mathrm{H}_{2} \mathrm{O}$ \\
\hline $\mathrm{C}_{3} \mathrm{H}_{8} \mathrm{O}_{3}+5 \mathrm{H}_{2}$ & $3 \mathrm{CH}_{4}+3 \mathrm{H}_{2} \mathrm{O}$ \\
\hline $\mathrm{C}_{3} \mathrm{H}_{8} \mathrm{O}_{3}$ & $\leftrightarrow \quad \mathrm{C}_{2} \mathrm{H}_{4}+\mathrm{CO}+2 \mathrm{H}_{2} \mathrm{O}$ \\
\hline $\mathrm{CO}+3 \mathrm{H}_{2}$ & $\mathrm{CH}_{4}+\mathrm{H}_{2} \mathrm{O}$ \\
\hline $\mathrm{CO}_{2}+2 \mathrm{H}_{2}$ & $2 \mathrm{H}_{2} \mathrm{O}+\mathrm{C}(\mathrm{s})$ \\
\hline $\mathrm{CO}_{2}+4 \mathrm{H}_{2}$ & $\mathrm{CH}_{4}+2 \mathrm{H}_{2} \mathrm{O}$ \\
\hline $\mathrm{CO}_{2}+\mathrm{CH}_{4}$ & $2 \mathrm{CO}+2 \mathrm{H}_{2}$ \\
\hline $\mathrm{CH}_{4}$ & $2 \mathrm{H}_{2}+\mathrm{C}(\mathrm{s})$ \\
\hline $\mathrm{C}_{2} \mathrm{H}_{4}$ & $2 \mathrm{H}_{2}+2 \mathrm{C}(\mathrm{s})$ \\
\hline $2 \mathrm{CO}$ & $\mathrm{C}(\mathrm{s})+\mathrm{CO}_{2}$ \\
\hline $\mathrm{C}(\mathrm{s})+\mathrm{H}_{2} \mathrm{O}$ & $\mathrm{CO}+\mathrm{H}_{2}$ \\
\hline $\begin{aligned} & \mathrm{C}_{2} \mathrm{H}_{4} \\
+ & \mathrm{H}_{2}\end{aligned}$ & $\mathrm{C}_{2} \mathrm{H}_{6}$ \\
\hline
\end{tabular}


As in the process of methane steam reforming, nickel based catalysts are the most widely studied for the dry reforming of methane, although noble metals ( $\mathrm{Pt}, \mathrm{Rh}, \mathrm{Ir}, \mathrm{Ru}$, $\mathrm{Rh}$ ) have also been reported extensively in scientific literature. It may be expected that, as in the case of methane steam reforming, the use of noble metals would be too expensive for use in glycerol steam reforming on an industrial scale, and nickel based catalysts would be employed in practice.

Many studies of nickel based catalysts with a variety of supports have been reported in the literature. Table 2 shows a list of such works, including details of the amount of nickel in the catalyst, the type of support and the water/glycerol molar ratio (WGR) employed. One striking fact revealed in this list is the large number of researchers who have employed water/glycerol molar ratios equal to or larger than 6. According to equation 1 the stoichiometric ratio for hydrogen production is 3 , and much lower ratios should be used if the target is to produce syngas. The explanation for the large water/glycerol ratio is the need to avoid coke deposition on the catalyst surface, which is often quicker in the case of nickel rather than noble metal catalysts. However, the use of a large excess of steam would imply that a significant amount of the energy contained in the glycerol (or the equivalent amount from another fuel) would be employed simply to produce steam. This would be uneconomic in industrial applications, and therefore ways to reduce the steam/glycerol molar ratio are highly desirable. In fact the same could be said for most steam reforming processes, as is reflected in industrial efforts to decrease the steam/carbon ratio in methane steam reforming (e.g. [6,7]). Carbon deposition can cause a decrease in catalyst activity by encapsulation of metallic particles or coverage of the catalytic surface by amorphous coke. Under some conditions carbon whiskers are formed; although they do not produce a direct loss of activity, these whiskers can break the catalyst particles and block the gas flow in a fixed bed.

One way to reduce or even totally counteract the effect of coke formation in a catalytic reaction is the use of a Two-Zone Fluidized Bed Reactor (TZFBR). This device has been previously tested by our group for several reactions [8-10], showing that in many cases it is possible to achieve steady state operation under conditions where a conventional reactor would suffer catalyst deactivation. The use of a TZFBR has also been found to be beneficial for the oxidative coupling of methane by Talebizadeh et al. [11] and for oxidative dehydrogenation of butane by Rischard et al. [12] and has been 
proposed for glycerol dehydration to acrolein [13]. A scheme of a TZFBR is shown in Figure 1. Two zones with different reaction environments are created in a fluidized bed by feeding two streams at two different points: a reacting gas (e.g. a hydrocarbon) is fed at an intermediate point of a fluidized bed of catalyst and a second gas for regeneration (e.g. oxygen) is fed at the bottom of the bed. The desired reaction (e.g. hydrocarbon reforming) is produced in the upper part of the bed and the catalyst regeneration occurs in the lower part. The continuous mixing of solid (caused by bubbles in a fluidized bed) transports the solid between both zones. In this way a dynamic equilibrium is achieved between coke formation in the upper zone and coke removal in the lower zone.

There is a clear incentive for the use of crude glycerol in this process, since its price is much lower than that of refined glycerol. The main problem for the use of crude glycerol could be the presence of salts (e.g. $\mathrm{NaCl}$ or $\mathrm{Na}_{2} \mathrm{SO}_{4}$ ) that would be deposited in the solid when the feed is vaporized. A potential advantage of using fluidized bed reactors could be that the inorganic salts found in crude glycerol would be deposited on the external surface of the catalyst, being easily removed by attrition and collected by external filters. This advantage has been found experimentally in a previous work [1415] on the decomposition of crude glycerol for acrolein production.

This work aims to study the feasibility of using a TZFBR for glycerol reforming. In addition to some preliminary experiments in the absence of a catalyst and in a fixed bed reactor, the main part of the experimental work was devoted to comparing the performance of a conventional fluidized bed with that of a TZFBR. In addition, several regenerating gases have been studied in the TZFBR, including $\mathrm{H}_{2} \mathrm{O}, \mathrm{O}_{2}$ and $\mathrm{CO}_{2}$. 
Table 2. Ni based catalysts and water/glycerol molar ratio (WGR) employed by several authors

\begin{tabular}{|c|c|c|c|c|}
\hline$\% \mathrm{Ni}$ & Support & $\mathrm{T}\left({ }^{\circ} \mathrm{C}\right)$ & WGR & Ref. \\
\hline $2-5$ & $\mathrm{SiO} 2$ & $350-450$ & 46 & {$[16]$} \\
\hline 2 & $\mathrm{Ce}-\mathrm{Zr} / \mathrm{Al}_{2} \mathrm{O}_{3}$ & $450-600$ & 6 & [17] \\
\hline 2.5 & $\mathrm{Ce} / \mathrm{Al} 2 \mathrm{O} 3$ & $600-900$ & 6 & [18] \\
\hline 4 & $\mathrm{Al}_{2} \mathrm{O}_{3}$ & $500-700$ & 6 & [19] \\
\hline 5 & $\begin{array}{l}\text { M-Ce } / \mathrm{Al}_{2} \mathrm{O}_{3} \\
(\mathrm{M}=\mathrm{Pt}, \mathrm{Ir}, \mathrm{Pd}, \mathrm{Ru})\end{array}$ & 700 & 6 & [20] \\
\hline 5.1 & $\mathrm{Al}_{2} \mathrm{O}_{3}$ & 700 & 3 & [21] \\
\hline $5-20$ & $\mathrm{Al}_{2} \mathrm{O}_{3}$ & $400-600$ & $3-12$ & [22] \\
\hline $5-20$ & $\mathrm{Al}_{2} \mathrm{O}_{3} ; \mathrm{Al}_{2} \mathrm{O}_{3}-\mathrm{MgO}$ & 600 & 9 & [23] \\
\hline 5.8 & $\mathrm{Al}_{2} \mathrm{O}_{3}$ & $600-700$ & 16 & [24] \\
\hline 7 & SBA-15 & 600 & 6 & [25] \\
\hline 7.8 & LTA/CaO-LTA/MgO & 600 & 9 & [26] \\
\hline $9.6-12.7$ & $\mathrm{CeO}_{2}, \mathrm{MgO}, \mathrm{TiO}_{2}$ & $550-650$ & $6-12$ & [27] \\
\hline 10 & $\mathrm{TiO}_{2}, \mathrm{SBA}-15, \mathrm{ZrO}_{2}$ & $500-650$ & 46 & [28] \\
\hline 10 & CeZrO & $500-700$ & $6-24$ & [29] \\
\hline 10 & $\mathrm{La}_{2} \mathrm{O}_{3}-\mathrm{SiO}_{2}$ & 600 & 9 & [30] \\
\hline 10 & $\mathrm{Al}_{2} \mathrm{O}_{3}$ & 600 & 24 & [31] \\
\hline 10 & $\mathrm{Al}_{2} \mathrm{O}_{3}-\mathrm{MgO}$ & 600 & 9 & [32] \\
\hline 10 & $\mathrm{Al}_{2} \mathrm{O}_{3}-\mathrm{CaO}-\mathrm{MgO}$ & 750 & 9 & [33] \\
\hline 12.6 & $\mathrm{La}_{2} \mathrm{O}_{3}-\mathrm{Al}_{2} \mathrm{O}_{3}$ & 500 & 46 & [34] \\
\hline $12.6-13.4$ & $\mathrm{Al}_{2} \mathrm{O}_{3}+(\mathrm{Mg}, \mathrm{Ce}, \mathrm{La}, \mathrm{Zr})$ & 600 & 507 & [35] \\
\hline 13 & $\mathrm{CeO}_{2}-\mathrm{Al}_{2} \mathrm{O}_{3}$ & $500-600$ & 46 & [36] \\
\hline 14.1 & $\mathrm{Al}_{2} \mathrm{O}_{3}$ & $400-700$ & 9 & [37] \\
\hline 14.1 & $\mathrm{Al}_{2} \mathrm{O}_{3}$ & $400-700$ & 9 & [38] \\
\hline 15 & $\mathrm{MgO}, \mathrm{CeO} 2, \mathrm{TiO} 2$ & $550-650$ & 6 & [39] \\
\hline 15 & $\mathrm{Al}_{2} \mathrm{O}_{3}$ & 550 & $3-12$ & [40] \\
\hline 15 & $(\mathrm{~K}, \mathrm{Ca}, \mathrm{Sr})-\mathrm{Al}_{2} \mathrm{O}_{3}$ & $600-800$ & 9 & [41] \\
\hline 15 & $\mathrm{CeO}_{2}$ & $400-550$ & 9 & [42] \\
\hline 15 & $\mathrm{CeO}_{2}-\mathrm{ZrO}_{2}$ & $600-700$ & $20-46$ & [43] \\
\hline $19-35$ & $\mathrm{Al}_{2} \mathrm{O}_{3} / \mathrm{MgO}$ & $450-650$ & 9 & [44] \\
\hline $21-30$ & $\mathrm{Al}_{2} \mathrm{O}_{3}, \mathrm{MgO}, \mathrm{CeO}_{2}$ & 800 & 9 & [45] \\
\hline 23 & $\mathrm{Lal}_{2} \mathrm{O}_{3}$ & 550 & 9 & [46] \\
\hline $23-51$ & $\begin{array}{l}\mathrm{MgO}, \mathrm{CuO} / \mathrm{MgO} \text {, } \\
\mathrm{CuO} / \mathrm{Al}_{2} \mathrm{O}_{3}\end{array}$ & $150-650$ & $>9$ & [47] \\
\hline 57 & $\mathrm{SiO}_{2}$ & $500-600$ & $9-18$ & [48] \\
\hline
\end{tabular}




\section{Experimental system}

\subsection{Catalyst}

The catalyst employed in this study is a $\mathrm{Ni} / \mathrm{Al}_{2} \mathrm{O}_{3}$, prepared by incipient impregnation of alumina particles to achieve a Ni content of $5 \%$ by weight. The Ni content is lower than in conventional catalysts employed for methane steam reforming, but our previous experiments showed that commercial steam reforming catalysts, after being crushed and sieved for use in a fluidized bed reactor, were not suitable for fluidization because they were prone to agglomeration under the operating conditions used. Therefore, a catalyst with lower nickel content was selected, prepared on a suitable support for use in a fluidized bed. The support was a fluidizable alumina (Sasol, Puralox SCCa-150/200), previously calcined at $950^{\circ} \mathrm{C}$ to achieve a stable material under reaction conditions. Impregnation was carried out by the incipient wetness method. A solution of $\mathrm{Ni}\left(\mathrm{NO}_{3}\right)_{2}$ with a concentration able to achieve $5 \%$ by weight in the final catalyst was added. The mixture was dried at $120^{\circ} \mathrm{C}$ and calcined at $950^{\circ} \mathrm{C}$. A fraction with a particle size between 105 and $150 \mu \mathrm{m}$ was selected. Its minimum fluidization velocity, measured with nitrogen at $700^{\circ} \mathrm{C}$, was $3.91 \mathrm{~cm}^{3}(\mathrm{STP}) / \mathrm{cm}^{2}$.min.

\subsection{Reactors}

A few experiments were done in a conventional fixed bed reactor, where $1 \mathrm{~g}$ of catalyst was placed in a quartz tube $(1 \mathrm{~cm}$ i.d.) between glass wool stoppers. In most cases fluidized bed reactors were employed. Two types of fluidized bed reactor were used in this work: a conventional fluidized bed reactor and a two-zone fluidized bed reactor. Both are made of quartz, $2.8 \mathrm{~cm}$ i.d. with a porous quartz plate as gas distributor. The stream at the reactor exit was cooled; the condensed products were analyzed by CG-MS and the gaseous products by GC with a FID detector. The catalyst was regenerated with oxygen after the reaction and the amount of coke formed during the reaction was calculated from the amount of $\mathrm{CO}$ and $\mathrm{CO}_{2}$ formed.

Reaction results are reported as gas composition in a dry and nitrogen free basis, or as selectivity or yield. Yield to hydrogen is given by

Yield to $H_{2}=\frac{F_{H 2}}{7 F_{g o}}$ 
where $F_{H 2}$ is the molar flow of hydrogen in the exit stream and $F_{g o}$ is the molar flow of glycerol in the feed. The constant 7 arises from the stoichiometric coefficient of hydrogen in Equation 1.

In similar way, the selectivity to other compounds is calculated in a carbon basis,

Selectivity to $j=\frac{m_{j} F_{j}}{3\left(F_{g o}-F_{g}\right)}$

where $m_{j}$ is the number of carbon atoms in compound $j, F_{j}$ is the molar flow rate of compound $\mathrm{j}$ in the exit stream and $F_{g}$ is the molar flow rate of glycerol in the exit stream.

In some cases the selectivity to $\mathrm{C}_{2+}$ is reported, where $\mathrm{C}_{2+}$ includes the sum of all gaseous products with two or more carbon atoms (ethane, ethylene, acetylene, propane, and propene).

\section{Results and discussion}

\subsection{Blank reaction}

Blank reaction experiments, i.e. in an empty reactor, were made to check the glycerol decomposition and the product distribution in the absence of a catalyst. The feed was a water-glycerol-nitrogen mixture with a molar ratio of 9:1:1 and a flow of glycerol of $0.15 \mathrm{~mL} / \mathrm{min}$. The temperature was varied between 600 and $800^{\circ} \mathrm{C}$. The results are shown in Figure 2. It is worth mentioning the high conversion of glycerol that was achieved in the absence of catalyst, showing that the gas phase reactions have a significant contribution over $600^{\circ} \mathrm{C}$. It can be said that the process may be considered, at least in part, as the steam reforming of glycerol decomposition products [49]. At $700^{\circ} \mathrm{C}$ the conversion of glycerol is almost total. The products of thermal decomposition include a significant number of oxygenated products, which are lumped together under the concept of "liquids". They include acetaldehyde, hydroxyacetone, acetone, acetaldehyde and phenol. These are expected intermediates in glycerol decomposition and have been reported by other authors [45]. The high selectivity to $\mathrm{C}_{2} \mathrm{H}_{4}$, up to $25 \%$, is also noteworthy. The relatively low hydrogen yield achieved (only $8.6 \%$ at $700^{\circ} \mathrm{C}$ ) points to the need for a catalyst to obtain hydrogen or syngas. In any case, it is clear that at temperatures over $600^{\circ} \mathrm{C}$, most of the glycerol conversion occurs in the gas phase, and thus the role of the catalyst is better described by saying that it is responsible 
for the reforming of glycerol decomposition products rather than the direct reforming of glycerol itself.

\subsection{Packed bed reactor}

Experiments were carried out in a fixed bed reactor with two WGRs: 3 and 1.25. The catalyst described in the experimental methods section $\left(5 \% \mathrm{Ni} / \mathrm{Al}_{2} \mathrm{O}_{3}\right)$ was employed. In the first experiment a small bed ( $1 \mathrm{~g}$ ) of catalyst was employed in a quartz tube of 0.9 cm i.d. In the second experiment a large bed (34.5 g) was placed in the same reactor employed for fluidized bed experiments $(2.8 \mathrm{~cm}$ i.d.). Some nitrogen was also added, required by the experimental system to help in the vaporization of the water/glycerol mixture. The total gas flow rate was varied in such a way that a similar linear gas velocity was employed in both experiments. Table 3 summarizes the experimental conditions in both reactors. In the first case it was possible to operate for several hours (up to $15 \mathrm{~h}$ ) with only small changes in the conversion or gas distribution of products. The mean composition of the exit flow obtained was similar to that predicted by the thermodynamic equilibrium (calculated with the Gibbs reactor module of Hysys), as shown in Table 4. However, the last experimental points showed an increase in the amount of $\mathrm{C}_{2} \mathrm{H}_{4}, \mathrm{C}_{2} \mathrm{H}_{6}$ and oxygenated products (even if the selectivity to these was below $0.1 \%$ ). This increase evidences the effect of catalyst deactivation. Experiment PB-1 was repeated with different values of time-on-stream, taking samples of catalyst and measuring the coke content by TGA. Figure 3 shows the evolution of coke content with time, with values as high as $20 \mathrm{wt} \%$ after $15 \mathrm{~h}$.

Table 3. Experiments in packed bed reactor. WGN stands for water:glycerol:nitrogen molar ratio in the feed.

\begin{tabular}{llccc} 
Experiment & $\begin{array}{l}\text { Weight of } \\
\text { catalyst }(\mathrm{g})\end{array}$ & $\begin{array}{c}\text { Temperature } \\
\left({ }^{\circ} \mathrm{C}\right)\end{array}$ & WGN & $\begin{array}{c}\mathrm{Q} \\
(\mathrm{mL}(\mathrm{STP}) / \mathrm{min})\end{array}$ \\
\hline PB-1 & 1 & $650^{\circ} \mathrm{C}$ & $3: 1: 1$ & 22.4 \\
PB-2 & 34.5 & $650^{\circ} \mathrm{C}$ & $1.25: 1: 1.75$ & 179
\end{tabular}

Table 4. Mean composition of the exit gas stream in experiment PB-1 and values predicted by thermodynamic equilibrium (in dry basis and without nitrogen).

\begin{tabular}{lllll} 
Molar \% & $\mathrm{H}_{2}$ & $\mathrm{CO}$ & $\mathrm{CO}_{2}$ & $\mathrm{CH}_{4}$ \\
\hline experimental & 61.1 & 18.5 & 16.1 & 3.26 \\
equilibrium & 60.4 & 19.2 & 17.2 & 3.20
\end{tabular}

Figure 3. 
When the WGR was reduced to 1.25, as in experiment PB-2, the problems related with coke formation were much more severe. In fact, the experiment had to be stopped after 40 minutes because the coke build-up was so large that the bed became plugged and the pressure drop suddenly increased. Figure 4 shows an image of the bed, where the layer of coke formed in the top of the bed can be seen. The average content of coke in the bed (measured by TGA) was $10.6 \mathrm{wt} \%$, although the image suggests that the coke concentration was greater in the upper part of the bed.

Figure 4.

\subsection{Fluidized bed reactor experiments}

Some of the problems associated with coke formation can be avoided by using fluidized bed reactors. Plugging of the catalyst bed was not observed in these reactors, even in the worst conditions (low reaction temperature and low steam/glycerol ratio). As an example, Figure 5 shows the results obtained in two fluidized bed reactors with different amounts of catalyst (10 and $34.5 \mathrm{~g}$ ). The selectivity to gaseous products was greater with the smaller amount of catalyst, while the selectivity to coke was higher when the higher mass of catalyst was employed. In both cases the amount of liquid products obtained was negligible. In the experiment with $10 \mathrm{~g}$ of catalyst the deactivation affected the hydrogen yield after $150 \mathrm{~min}$, while this decrease was not observed with $34.5 \mathrm{~g}$ with a similar time-on-stream. The effect of catalyst deactivation was also observed with $10 \mathrm{~g}$ of catalyst by the increase in the formation of $\mathrm{CH}_{4}$ and $\mathrm{C}_{2}$ hydrocarbons (ethane and ethylene). Although the decrease in hydrogen yield by catalyst deactivation was not observed with $34.5 \mathrm{~g}$, the selectivity to coke was high under these conditions (higher than 10\%). It seems obvious that after some time the catalyst will be deactivated by coke formation.

Figure 5

Experiments co-feeding $\mathrm{O}_{2}$ (5\% by volume) or $\mathrm{CO}_{2}$ (20\%) together with glycerol and water showed lower concentrations of hydrogen in the exit stream, and the yield to hydrogen decreased continuously along the time-on-stream (Figure 6). Oxygen conversion was always complete, i.e. no oxygen was found in the exit stream. These results suggest that when $\mathrm{O}_{2}$ or $\mathrm{CO}_{2}$ is co-fed with glycerol, the catalyst deactivation by coke is not avoided. In fact the yield to hydrogen is clearly lower when $\mathrm{O}_{2}$ or $\mathrm{CO}_{2}$ is fed, although the percentage of water in the feed is similar in the three cases ( $31 \%$ when 
only water is used as a regenerating gas, $33 \%$ when $\mathrm{O}_{2}$ was added and $25 \%$ when $\mathrm{CO}_{2}$ was added). The effect of catalyst deactivation is also evidenced by the large formation of $\mathrm{CH}_{4}$ and $\mathrm{C}_{2}$ hydrocarbons (not shown in Figure 6), which was also larger when $\mathrm{O}_{2}$ or $\mathrm{CO}_{2}$ was used as the regenerating gas. These results suggest that neither $\mathrm{O}_{2}$ nor $\mathrm{CO}_{2}$ can be used in a conventional fluidized bed to counteract the catalyst deactivation.

Figure 6

As may be expected, the yield to hydrogen strongly depends on the temperature and the steam/glycerol ratio. The effect of these operating variables is shown in Figure 7, using the steam/carbon ratio, the usual practice in the gas industry, instead of the steam/glycerol molar ratio. The increase in temperature from $600^{\circ} \mathrm{C}$ to $700^{\circ} \mathrm{C}$ slightly raised the hydrogen yield, achieving in both cases values close to the thermodynamic equilibrium. The effect of the steam/carbon molar ratio was even greater, with the hydrogen yield rising from around $47 \%$ to $60 \%$ when this ratio was raised from 0.3 to 1 .

Figure 7

\subsection{Two-zone fluidized bed reactor}

The coke formation observed under most operating conditions, especially when a low steam/glycerol molar ratio was employed in a conventional fluidized bed reactor, suggests that the catalyst will be deactivated by coke. This catalyst deactivation would require to stop the process at some point for catalyst regeneration. The following experiments were conducted using a TZFBR in order to provide a comparison with a conventional reactor and to explore the effect of the operating conditions on its performance.

A comparison between the performance of a conventional fluidized bed reactor and a TZFBR with the same feed and the same total amount of catalyst is shown in Figure 8. The selectivity to gaseous products is high in both reactors, but higher in the TZRBR. A lower selectivity to coke was obtained in the TZFBR, which can be explained by the regeneration effect in the lower part of the reactor. The yield to hydrogen in the TZFBR was higher and more stable than in the conventional reactor. The selectivity to $C_{2}$ hydrocarbons was lower in the conventional reactor, probably because the amount of catalyst in the reaction zone was larger than in the TZFBR (height of the reaction zone: $7 \mathrm{~cm}$ instead of c.a. $2 \mathrm{~cm}$ ). The main conclusion from this experiment is the capability of the TZFBR to counteract coke formation by the in-situ regeneration in the lower part 
of the reactor, which suggests that it is possible to operate for a considerable time without noticing the effects of catalyst deactivation by coke.

The capability of the TZFBR to operate with low WGR is shown in Figure 9. In these experiments the WGR was varied from 5:1 to 1:1, while keeping the total flow rate constant, by replacing water with nitrogen. As an exception, in the experiment with WGR $=5$ the total flow was slightly lower. In all cases total glycerol conversion was achieved. Figure 9 also shows as a continuous line the concentration of each gas predicted by thermodynamic equilibrium. In all cases a steady hydrogen yield was achieved during $4 \mathrm{~h}$ experiments.

\subsubsection{Effect of gas velocity}

A series of experiments was made varying the gas velocity in the upper part (reaction zone) of the reactor, while keeping it constant in the lower part. In these experiments the relative velocity (i.e. the ratio of gas velocity to minimum fluidization velocity) in the lower part of the reactor $\left(\mathrm{u}_{\mathrm{r}, \mathrm{b}}\right)$ was kept equal to two, while the relative velocity in the upper part was varied between 3.5 and 8 . The feed to the reactor bottom was water and nitrogen (25\% water). The intermediate feed was a mixture of water, glycerol and nitrogen (in a molar ratio of 1:1:1). The global water/glycerol/nitrogen molar ratio (WGN), the total gas flowrate (Q) and the glycerol feed rate in each experiment is shown in table 6.

Table 6. Experiments with variable reduced velocity in the upper zone of the TZFBR. $34.5 \mathrm{~g}$ of catalyst. $\mathrm{T}=650^{\circ} \mathrm{C}$.

\begin{tabular}{|l|l|c|c|}
\hline $\mathrm{u}_{\mathrm{r}, \mathrm{u}}$ & WGN & $\mathrm{Q}\left(\mathrm{ml}(\mathrm{STP}) \cdot \mathrm{min}^{-1}\right)$ & $\begin{array}{c}\text { Glycerol feed } \\
\left(\mu \mathrm{LL} \cdot \mathrm{min}^{-1}\right)\end{array}$ \\
\hline 3.5 & $2: 1: 4$ & 80 & 22.88 \\
\hline 4 & $1.74: 1: 3.25$ & 91 & 30.51 \\
\hline 5 & $1.59: 1: 2.81$ & 102 & 38.14 \\
\hline 4.5 & $1.49: 1: 2.50$ & 114 & 45.77 \\
\hline 5 & $1.42: 1: 2.28$ & 125 & 53.40 \\
\hline 5.5 & $1.37: 1: 2.13$ & 136 & 61.02 \\
\hline 6 & $1.33: 1: 2$ & 148 & 68.65 \\
\hline 7 & $1.3: 1: 1.9$ & 159 & 76.28 \\
\hline 7.5 & $1.27: 1: 1.82$ & 170 & 83.91 \\
\hline 8 & $1.25: 1: 1.75$ & 182 & 91.53 \\
\hline
\end{tabular}

An almost constant gas composition was observed in each of these experiments after the first 100 min of time-on-stream (Figure 10), showing that the coke formation in the upper zone (reaction) was compensated for by coke removal in the lower zone (regeneration). The yield to hydrogen (Figure 11a) was close to the values predicted by 
the thermodynamic equilibrium. However, the higher the glycerol feed rate, the higher was the amount of coke remaining in the catalyst, as is shown in Figure 11b. These results show that the equilibrium between coke formation and coke removal is achieved at a greater coke concentration when the amount of glycerol fed is larger. The larger amount of coke also affects the formation of intermediate products. The yield to $\mathrm{C}_{2+}$ vs time-on-stream is shown in Figure 12 for several experiments with different relative velocity in the upper zone $\left(\mathrm{u}_{\mathrm{r}, \mathrm{u}}\right)$. Although this yield is quite low, always smaller than $2 \%$, some trends can be observed. In most cases a sharp increase is observed between 50 and $100 \mathrm{~min}$, followed by a period of much slower change. This trend is quite clear, on spite of some "peaks", probably due to the experimental error in the measurement of small concentrations. The higher the gas velocity $\left(\mathrm{u}_{\mathrm{r}, \mathrm{u}}\right)$, the higher is the yield to $\mathrm{C}_{2+}$ after 240 min. This suggests that the effect of coke formation (shown in Figure 11b) starts to affect the product distribution when a high gas velocity is employed.

\subsubsection{Effect of temperature}

A series of experiments was carried in a TZFBR with variable temperature, between 600 and $750^{\circ} \mathrm{C}$. The distribution of products is shown in Figure 13. The molar fraction of $\mathrm{CH}_{4}$ decreases with increasing temperature, both in the experimental results and in the thermodynamic equilibrium. The molar fraction of $\mathrm{CO}$ increases, with a corresponding decrease of the molar fraction of $\mathrm{CO}_{2}$, as the temperature increases. In the three cases the evolution with temperature of the experimental results closely follows the thermodynamic equilibrium predictions. In the case of hydrogen, the experimental value is slightly higher than the thermodynamic equilibrium prediction, the difference being higher at the lowest temperature. We found that at $600^{\circ} \mathrm{C}$ the selectivity to coke was still quite high (almost 40\%) after $240 \mathrm{~min}$, which suggests that at this temperature coke formation in the upper zone of the reactor was not compensated for by coke removal in the lower part. In fact, the coke content of the catalyst was much higher after the experiment at $600^{\circ} \mathrm{C}(7.8 \mathrm{wt} \%)$ than in the experiment at $750^{\circ} \mathrm{C}(2.2$ wt\%), which suggest a more effective regeneration in the lower zone at the higher temperature.

\subsubsection{Effect of oxygen as regenerating agent}

In the above experiments water was the only compound able to react with coke in the lower part of the reactor. This section describes results from experiments where some oxygen was added to the feed in the bottom of the reactor. In these experiments the 
percentage of oxygen in the feed was varied between 0 and 15\%, and the percentage of water was constant (25\%). The volumetric gas flowrate in the lower zone corresponds to twice that of minimum fluidization $\left(\mathrm{u}_{\mathrm{r}, \mathrm{b}}\right)$ and that added in the upper zone to six times that of minimum fluidization.

Figure 14 shows the change in the gas composition, given as the molar fraction of each compound, when the percentage of oxygen in the feed was varied. The main effect was an increase in $\mathrm{CO}_{2}$ in the products, together with a small decrease in the molar fraction of methane and hydrogen. The decrease in hydrogen yield was larger than that predicted by thermodynamic equilibrium, which suggests that when too large an amount of oxygen is employed (e.g. 15\%) the excess of oxygen is not only employed in a better regeneration, but also reaches the upper part of the reactor and burns some methane. In fact, when $15 \%$ oxygen was fed, the amount of $\mathrm{CO}_{2}$ was larger than that predicted by equilibrium. An additional effect of the increased amount of oxygen in the feed was the decrease in the coke content of the catalyst. This was $6.9 \mathrm{wt} \%$ when no oxygen was fed, decreasing to $5.6 \mathrm{wt} \%$ when the oxygen was raised to $5 \%$ and finally to $3.4 \%$ and $2.9 \%$ when the oxygen content was $10 \%$ and $15 \%$, respectively. It seems that the last increase in oxygen was only partially employed to burn coke and was also partially reacting with methane in the upper part of the reactor.

\subsubsection{Effect of carbon dioxide as regenerating agent}

The use of $\mathrm{CO}_{2}$ as a regenerating gas could be advantageous compared with oxygen from the safety point of view. There is a risk that some oxygen could reach the upper zone of the reactor or become mixed with methane in some way, which could possibly produce an explosion. With $\mathrm{CO}_{2}$ there is no such risk. Four experiments were done in which the amount of $\mathrm{CO}_{2}$ fed to the bottom of the reactor constituted between 20 and $100 \%$ of the feed in the lower part of the fluidized bed. These values correspond to 5 to $25 \%$ of the total feed. All the experiments were done with a steam/glycerol molar ratio of $1: 1$. Figure 15 shows the selectivity to gaseous products, the selectivity to coke and the yield to hydrogen over time for the four experiments. The selectivity to gaseous products was quite high after the first 60 minutes, mainly because the selectivity to coke was quite low after that time. In fact it was almost null in the experiments with pure $\mathrm{CO}_{2}$ in the feed to the reactor bottom, which is evidence that an equilibrium was achieved between coke formation in the upper part of the bed and coke removal by gasification with $\mathrm{CO}_{2}$ in the lower part of the bed. Similarly, the yield to hydrogen 
reached a plateau after 60 minutes, with a quite constant value. This yield was reasonably close to the value predicted by thermodynamic equilibrium. Small amounts of liquid products were found in these experiments, but the selectivity to these products, shown in Figure 16, was quite low, and almost null when pure $\mathrm{CO}_{2}$ was fed at the reactor bottom (making up 25\% of the total feed). The mean values of molar composition for the main products are plotted in figure 17 vs the percentage of $\mathrm{CO}_{2}$ in the feed, together with the continuous lines that correspond to the equilibrium. The evolution follows the same trend as the prediction from equilibrium. Methane remains at quite a low level (c.a. 5\%). The $\mathrm{H}_{2} / \mathrm{CO}$ ratio varied from 2.5 (in the absence of $\mathrm{CO}_{2}$ ) to 2 (when $25 \%$ of the feed was $\mathrm{CO}_{2}$ ), which may be a suitable $\mathrm{H}_{2} / \mathrm{CO}$ ratio for some applications (e.g. methanol synthesis).

The effect of the reaction temperature was studied by varying it between 650 and $750^{\circ} \mathrm{C}$, using a $\mathrm{WGR}=1$. The composition of the exit stream is given in Figure 18. We found that the higher the temperature, the higher was the $\mathrm{H}_{2}$ molar fraction, as may be expected since reforming reactions are mainly endothermal. In addition, the concentration of $\mathrm{CH}_{4}$ in the product stream decreased, consistent with the equilibrium predictions, becoming almost null at $750^{\circ} \mathrm{C}$. The decrease in $\mathrm{CH}_{4}$ and $\mathrm{CO}_{2}$ in the exit stream when the temperature was raised was accompanied by an increase in the molar fraction of $\mathrm{H}_{2}$ and $\mathrm{CO}$. These two compounds jointly account for $86 \%$ of the exit stream at the highest temperature.

\section{Conclusions}

The steam reforming of glycerol has been tested in several kinds of reactor, with an emphasis on low steam/glycerol ratios. It was found that the packed bed reactor was not suitable for the operating conditions, because the substantial coke formation led to plugging of the bed. A fluidized bed reactor was operated for a longer time, without suffering the effect of bed plugging in spite of the coke formation. The use of a twozone fluidized bed reactor, where the upper zone of the reactor is employed for glycerol reforming and the lower zone of the reactor is employed for catalyst regeneration by coke removal, was tested with several regenerating gases. In general, the two-zone fluidized bed reactor allowed the operation in steady state in conditions where a fluidized bed reactor would suffer catalyst deactivation by coke. It was found that the net coke formation rate approached zero after some time, because the rate of coke removal in the lower zone approximated the rate of coke formation in the upper zone. 
Water and $\mathrm{CO}_{2}$ were the most effective of the regenerating gases tested. The use of oxygen in the lower part of the reactor resulted in a lower activity, probably because the nickel was partially oxidized or some reforming products were burned when the amount of oxygen was too high. The use of carbon dioxide as a regenerating gas was found to be a viable alternative, which could provide an $\mathrm{H}_{2} / \mathrm{CO}$ ratio in the product stream suitable for some applications. In fact, since methanol is used in biodiesel manufacture, the production of methanol on-site could be a suitable way to employ crude glycerol. In addition, the use of $\mathrm{CO}_{2}$ instead of oxygen would make the system intrinsically safer, because the risk of the formation of an explosive atmosphere at some points of the reactor in the event of a malfunction (e.g. bypass by defluidization) would be avoided. The possibility of using $\mathrm{CO}_{2}$ as a regenerating gas, together with the energy advantage derived from using very low steam/glycerol ratios (as low as 1.25 in some cases), means that the two-zone fluidized bed reactor is a system with high potential in the steam reforming of glycerol. It may be expected that this potential could also be applied to the steam reforming of other feeds with a high tendency towards coke formation on the catalyst.

\section{Acknowledgements}

Financial support from MINECO, Spain (Projects ENE2013-44350-R and CTQ201676533-R) is gratefully acknowledged. Financial aid for the maintenance of the consolidated research group CREG has been provided by the Fondo Social Europeo (FSE) through the Gobierno de Aragón (Aragón, Spain). 


\section{References}

1. BP Statistical Review of World Energy. June 2017

2. Z.Gholami , A. Z. Abdullah , K. T. Lee, Renew. Sust. Energy Rev. 39 (2014) 327341.

3. M. Gupta, N. Kumar, Renew. Sust. Energy Rev. 16 (2012) 4551-4556.

4. Y. Lin, Int. J. Hydrog. Energy. 38 (2013) 2678-2700.

5. C. K. Cheng, S. Y. Foo, A. Adesina, Ind.Eng. Chem. Res. 49(1) (2010) 1080410817.

6. J.R. Rostrup-Nielsen, Catalyst deactivation 1991, in: C.H. Bartholomew, J.B. Butt (Eds.), Stud. Surf. Sci. Catal. 68 (1991) 85

7. I.I. Primdahl, T.S. Christensen, US Pat. 6,908,571 B2 (2005)

8. J. Herguido, M. Menéndez, J. Santamaría, Catal. Today. 100, (2005)181-189.

9. M. P. Lobera, C. Téllez, J. Herguido, M. Menéndez, Ind. Eng. Chem. Res. 47 (2008) 9314-9320.

10. J. Herguido, M. Menéndez, Current Opinion in Chem. Eng. 17 (2017) 1-7.

11. A. Talebizadeh, Y. Mortazavi, A. A. Khodadadi, Fuel Process. Technol., 90 (2009) 1319-1325.

12. J. Rischard, C. Antinori , L. Maier, O. Deutschmann, Applied Catal. A: Gral. 511 (2016) 23-30.

13. S. Pariente, V. Belliere-Baca, S. Paul, N. Fatah, US Patent 20130217909 (2011)

14. B. R. Sereshki, S. J. Balan, G. S. Patience, J. L. Dubois, Ind.Eng. Chem. Res. 49 (2010) 1050-1056.

15. J. L. Dubois, G. S. Patience, US Patent 20110028760 (2011).

16. F. Pompeo, G. F. Santori, N. N. Nichio, Catal. Today. 172 (2011)183-188.

17. I. N. Buffoni, F. Pompeo, G. F. Santori, N. N. Nichio, Catal. Comm. 10 (2009)16561660.

18. S. Adhikari, S. Fernando, A. Haryanto, Catal. Today. 129 (2007) 355-364.

19. E. A. Sanchez, R. A. Comelli, Int. J. Hydrog. Energy. 39 (2014)8650-8655.

20. L. P. R. Profeti, E. A. Ticianelli, E. M. Assaf, Int. J. Hydrog. Energy. 34 (2009)

5049-5060. 
21. E. A. Sanchez, R. A. Comelli, Int. J. Hydrog. Energy. 37 (2012)14740-14746.

22. A. Ebshish, Z. Yaakob, Y. H. Taufiq-Yap, A. Bshish, Materials. 7 (2014)22572272.

23. M. L. Dieuzeide, M. Jobbagy, N. Amadeo, Int. J. Hydrog. Energy. 39 (2014)1697616982.

24. E. A. Sánchez, M. A. D'Angelo, R. A. Comelli, Int. J. Hydrog. Energy. 35 (2010) 5902-5907.

25. J. A. Calles, A. Carrero, A. J. Vizcaíno, L. García-Moreno, Catal. Today. 227 (2014) 198-206.

26. Z.Y. Huang C.H Xu, J. Meng, C.F. Zheng, H. W. Xiao, J. Chen, Y.X. Zhang, J. Environ. Chem.l Eng. 2, (2014) 598-604.

27. S. Adhikari, S. D. Fernando, S. D. Filip To, R. M. Bricka, P. H. Steele, A. Haryanto, Energy Fuels. 22 (2008) 1220-1226.

28. V. Nichele, M. Signoretto, F. Menegazzo, A. Gallo, V. Dal Santo, G. Cruciani, G. Cerrato, Applied Catal. B: Enviro. 111-112 (2012)225-232.

29. S. Shao, A. Shi, C. Liu, R. Yang, W. Dong, Fuel Process. Technol. 125 (2014)1-7.

30. V. V. Thyssen, T. A. Maia, E. M. Assaf, Fuel. 105 (2013)358-363.

31. Y. Choi, N. D. Kim, J. Baek, W. Kim, H. J. Lee, J. Yi, Int. J. Hydrog. Energy. 36 (2011) 3844-3852.

32. M. L. Dieuzeide, M. Jobbagy, N. Amadeo, Catal. Today. 213 (2013) 50-57.

33. Z. Huang, C.H. Xu, C.Q. Liu, H.W. Xiao, J. Chen, Y.X. Zhang, Y.C. Lei, Korean J. Chem. Eng. 30 (2013) 587-592.

34. A. Iriondo, V. L. Barrio, J. F. Cambra, P. L. Arias, M. B. Güemez, R. M. Navarro, M. C. Sánchez-Sánchez, J. L. G. Fierro, Catal. Comm. 10 (2009) 1275-1278.

35. A. Iriondo, V. L. Barrio, J. F. Cambra, P. L. Arias, M. B. Güemez, R. M. Navarro, M. C. Sánchez-Sánchez, J. L. G. Fierro, Top. Catal. 49, (2008) 46-58.

36. A. Iriondo, V.L. Barrio, J.F. Cambra, P.L. Arias, M.B. Guemez,M.C. SanchezSanchez, R.M. Navarro, J.L.G. Fierro, Int. J. Hydrog. Energy. 35 (2010) 11622-11633.

37. B. Dou, V. Dupont, G. Rickett, N. Blakeman, P. T. Williams, H. Chen, Y. Ding, M. Ghadir, Bioresour. Technol. 100 (2009) 3540-3547.

38. B. Dou, G.L. Rickett, V Dupont, P.T. Williams, H. Chen, Y. Ding, M. Ghadiri, Bioresour. Technol. 101 (2010) 2436-2442.

39. S. Adhikari, S. D. Fernando, A. Haryanto, Renew. Energy. 33 (2008) 1097-1100. 
40. C. K. Cheng, S. Y. Foo, A. A. Adesina, Catal. Today. 178 (2011) 25-33.

41. X. Wang, M. Li, S. Li, H. Wang, S. Wang, X. Ma, Fuel Process. Technol. 91 (2010) 1812-1818.

42. B. Zhang, X. Tang, Y. Li, Y. Xu, W. Shen, Int. J. Hydrog. Energy. 32 (2007) 23672373.

43. C. D. Dave, K. K. Pant, Renew. Energy. 36 (2011) 3195-3202.

44. C. Wang, B. Dou, H. Chen, Y. Song, Y. Xu , X. Du, Ti. Luo, C. Tan. Chem. Eng. J. 220 (2013) 133-142.

45. V. Chiodo, S. Freni, A. Galvagno, N. Mondello, F. Frusteri, Applied Catal. A: Genl. 381 (2010) 1-7.

46. G. Wu, S. Li, C. Zhang, T. Wang, J. Gong, Applied Catal. B: Environ. 144 (2014) 277-285.

47. C. Wang, X. Wang, M. Li, Shuirong Li, S. Wang, X. Ma. Int. J. Hydrog. Energy 38 (2013) 3562-3571.

48. G. Sadanandam, N. Sreelatha, M. V. Phanikrishna Sharma, S. Kishta Reddy, B. Srinivas,K. Venkateswarlu, T. Krishnudu, M. Subrahmanyam, V. Durga Kumari. ISRN Chem. Eng. ID 591587, (2012).

49. L. F. Bobadill, , A. Penkova, F. Romero-Sarria, , M. A. Centeno, J. A. Odriozola, Int. J. Hydrog. Energy. 39 (2014) 5704-5712.

50. C. W. Bale and E. Bélisle, Fact-Web suite of interactive programs, www.factsage.com (accessed 17/07/2017) 
Figure 1. Scheme of a Two-Zone Fluidized Bed Reactor (TZFBR)

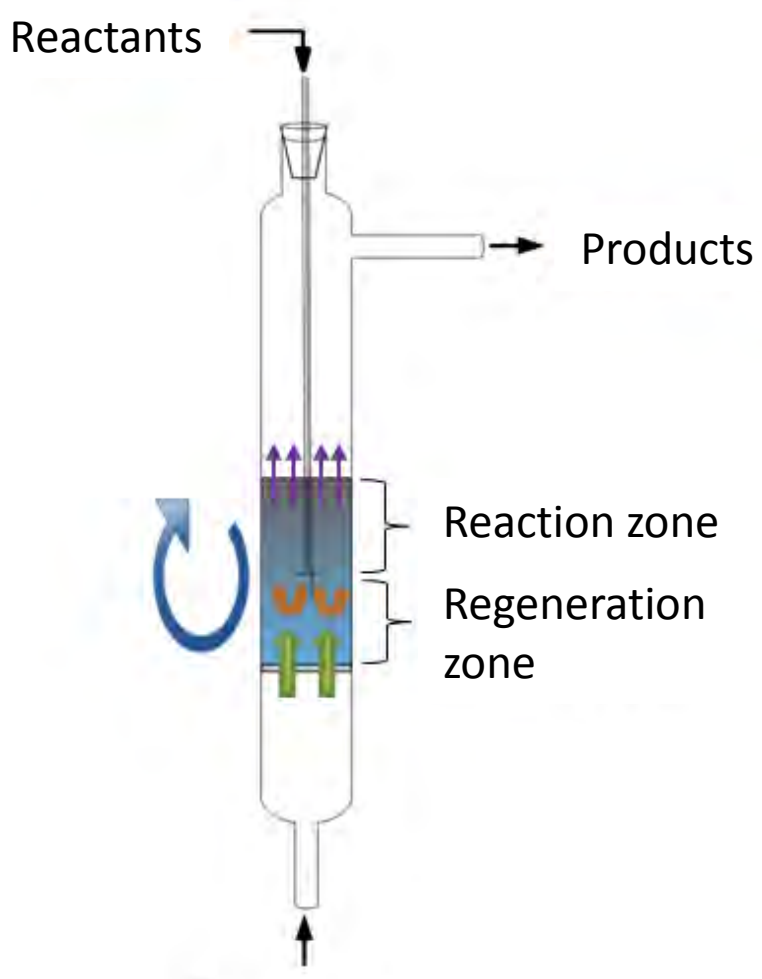

Regenerant 
Figure 2. Effect of temperature on the conversion, selectivity and yield to hydrogen in blank experiments. Molar ratio in the feed WGN $=9: 1: 1$, feed flowrate $=150$ $\mathrm{cm}^{3}(\mathrm{STP}) / \mathrm{min}$. Lines are only for visual help.
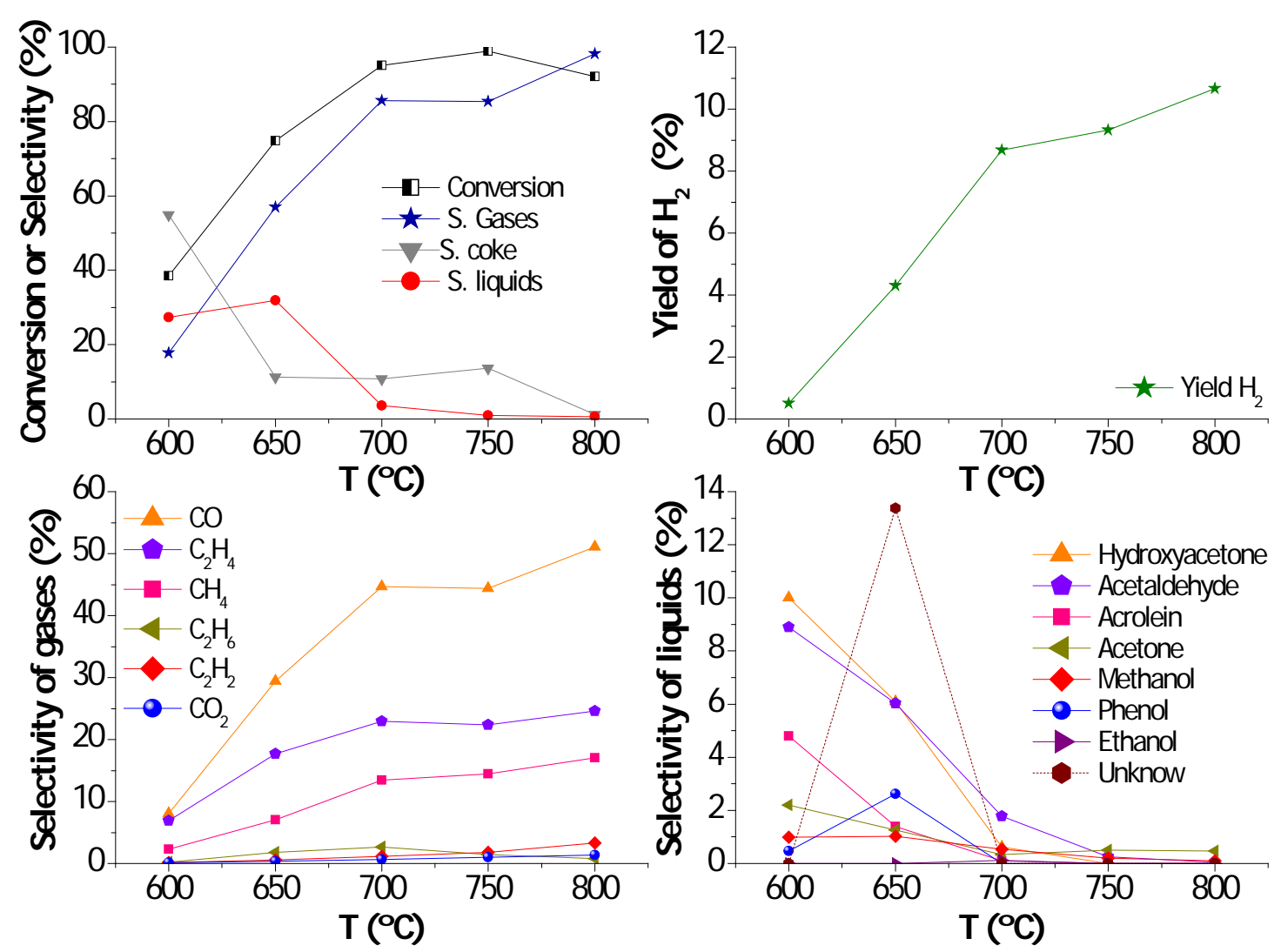
Figure 3. Coke formation vs time-on-stream in a packed bed reactor. Operating conditions: Table 3 (exp. PB-1).

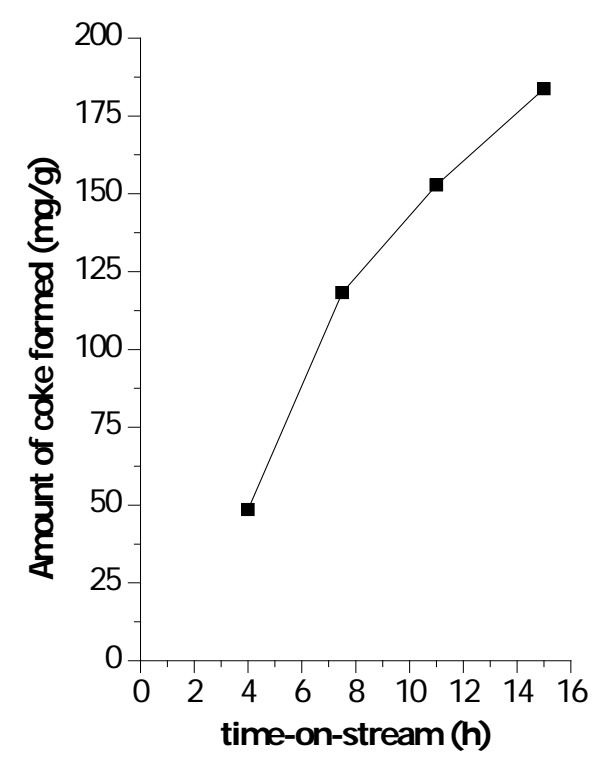


Figure 4. Picture of the bed plugged with coke after 40 min of time-on-stream (exp. PB$2)$.

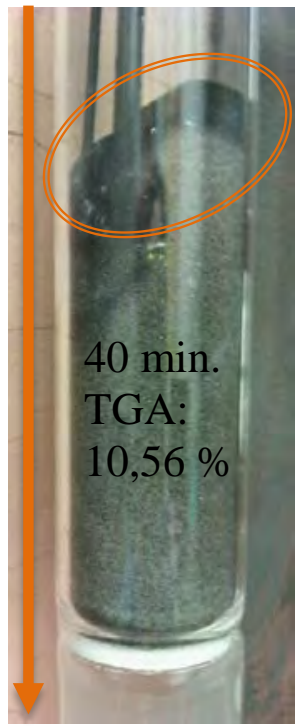


Figure 5. Results in conventional fluidized bed reactor with $10 \mathrm{~g}$ and $34.5 \mathrm{~g}$ of catalyst. Operating conditions: $650^{\circ} \mathrm{C}, \mathrm{WGN}=1.25: 1: 1.75 ; \mathrm{Q}=182 \mathrm{~cm}^{3}(\mathrm{STP}) / \mathrm{min}$. Full symbols: 34,5 g; Empty symbols: 10 g.(a) Selectivity to products and hydrogen yield, (b) composition of product gases (dry and $\mathrm{N}_{2}$ free bases). Lines are only for visual help. Dotted lines: equilibrium values.
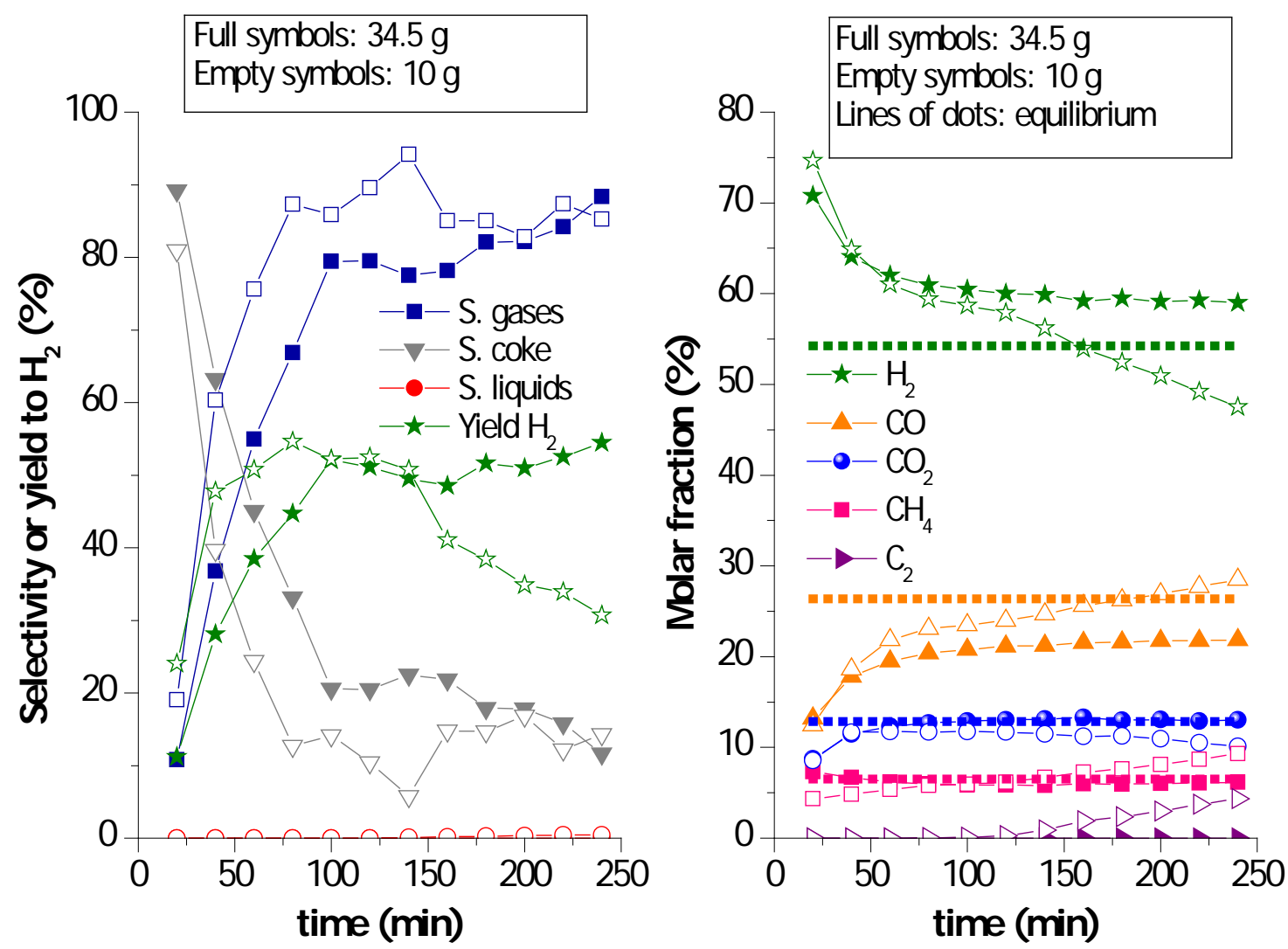
Figure 6. Conventional fluidized bed reactor performance using: a) only water as regenerating agent, b) $5 \%$ oxygen in the feed and c) $20 \% \mathrm{CO}_{2}$ in the feed. Left: conversion of glycerol. Center: selectivity to gases and yield to $\mathrm{H}_{2}$. Right: selectivity to coke and liquids. Operating conditions: $650^{\circ} \mathrm{C} ; \mathrm{W}=10 \mathrm{~g} ; \mathrm{Q}=182 \mathrm{~cm}^{3}(\mathrm{STP}) / \mathrm{min}$; Filled symbols: $\mathrm{H}_{2} \mathrm{O}$, empty symbols: $\mathrm{H}_{2} \mathrm{O}$ and $\mathrm{O}_{2}$; half-filled symbols: $\mathrm{H}_{2} \mathrm{O}$ and $\mathrm{CO}_{2}$.
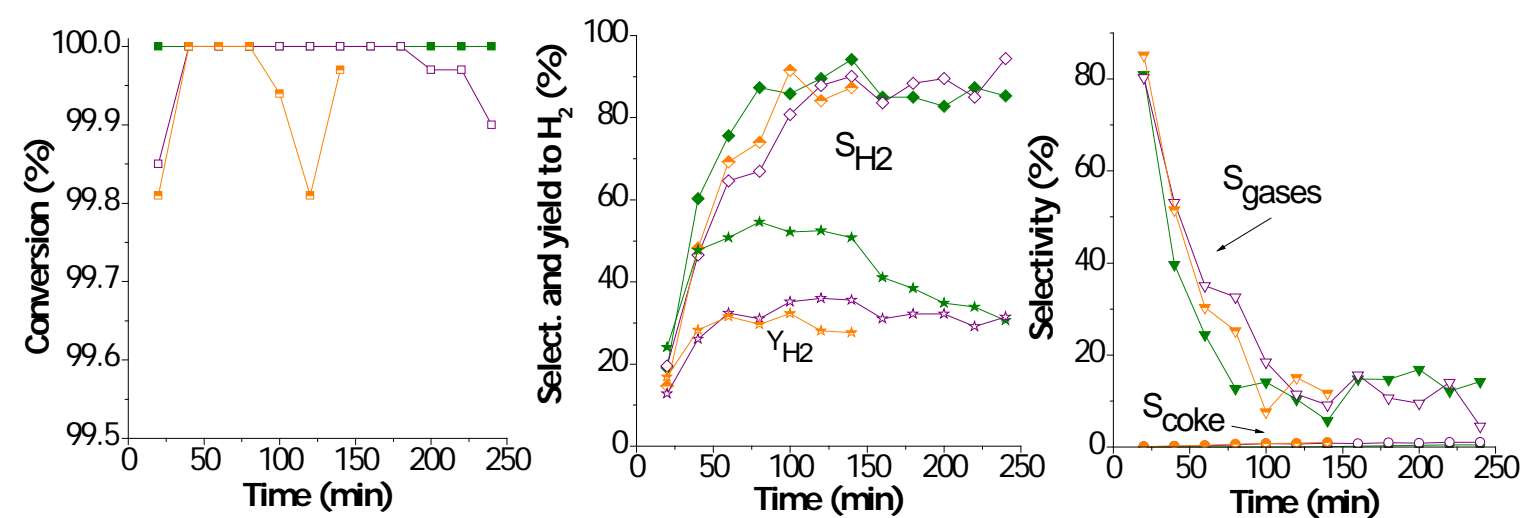
Figure 7. Effect of temperature (left) and steam/carbon molar ratio (right) in a conventional fluidized bed reactor. Experimental conditions: $\mathrm{Q}=112 \mathrm{~cm}^{3}(\mathrm{STP}) / \mathrm{min}$; W= 40 g; WGN = 9:1:1 (left figure); $650^{\circ} \mathrm{C}$ (right figure). Continuous lines: equilibrium; Symbols: experimental data.
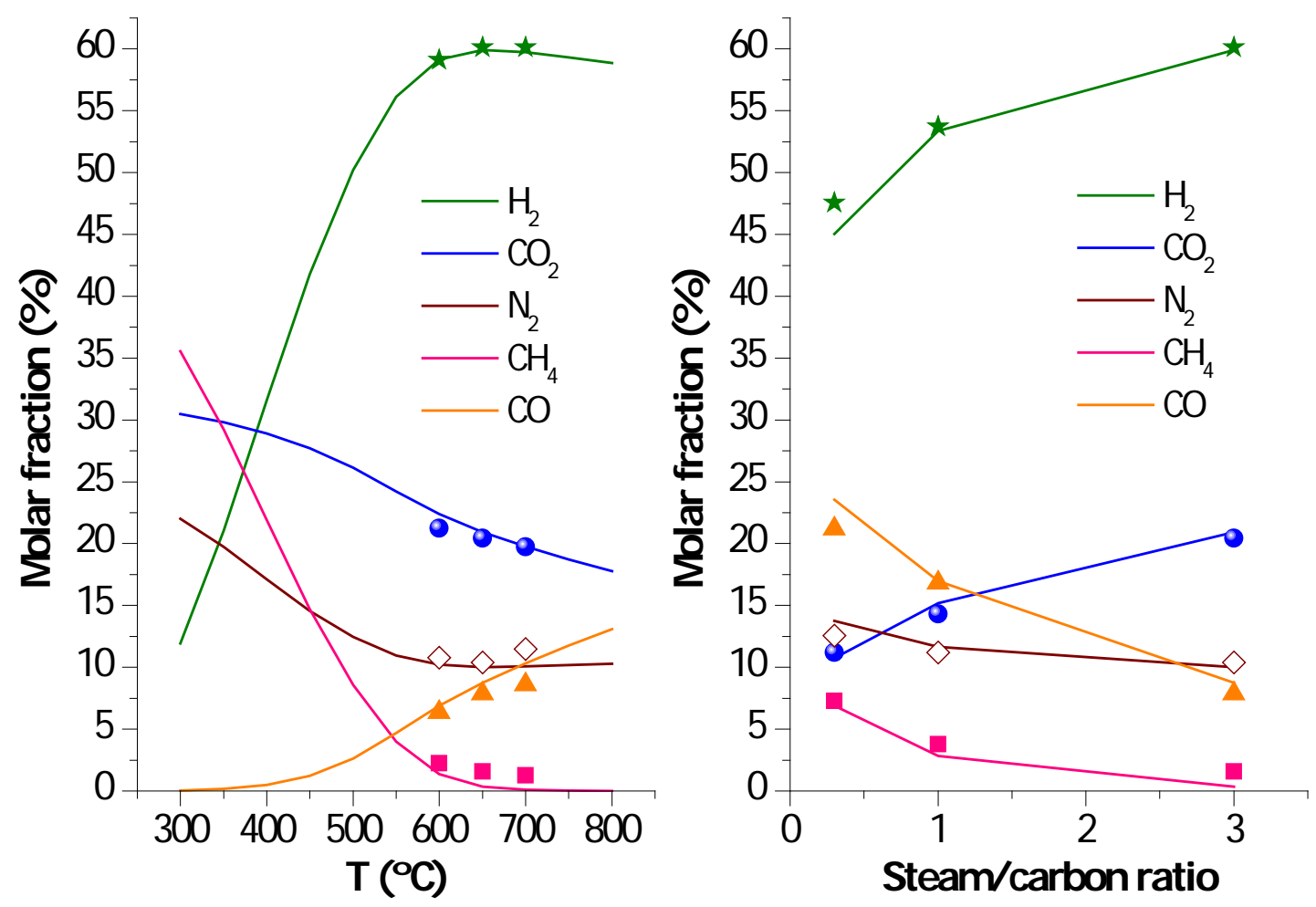
Figure 8. Comparison of conventional fluidized bed reactor (FBR)- full symbols- and Two-zone Fluidized Bed Reactor (TZFBR)-empty symbols. Experimental conditions: $\mathrm{T}=650^{\circ} \mathrm{C} ; \mathrm{Q}=182 \mathrm{~cm}^{3}(\mathrm{STP}) / \mathrm{min} ; \mathrm{W}=34.5 \mathrm{~g} ; \mathrm{WGN}=1.25: 1: 1.75$. Continuous lines are only for visual help. Dotted lines are thermodynamic equilibrium.
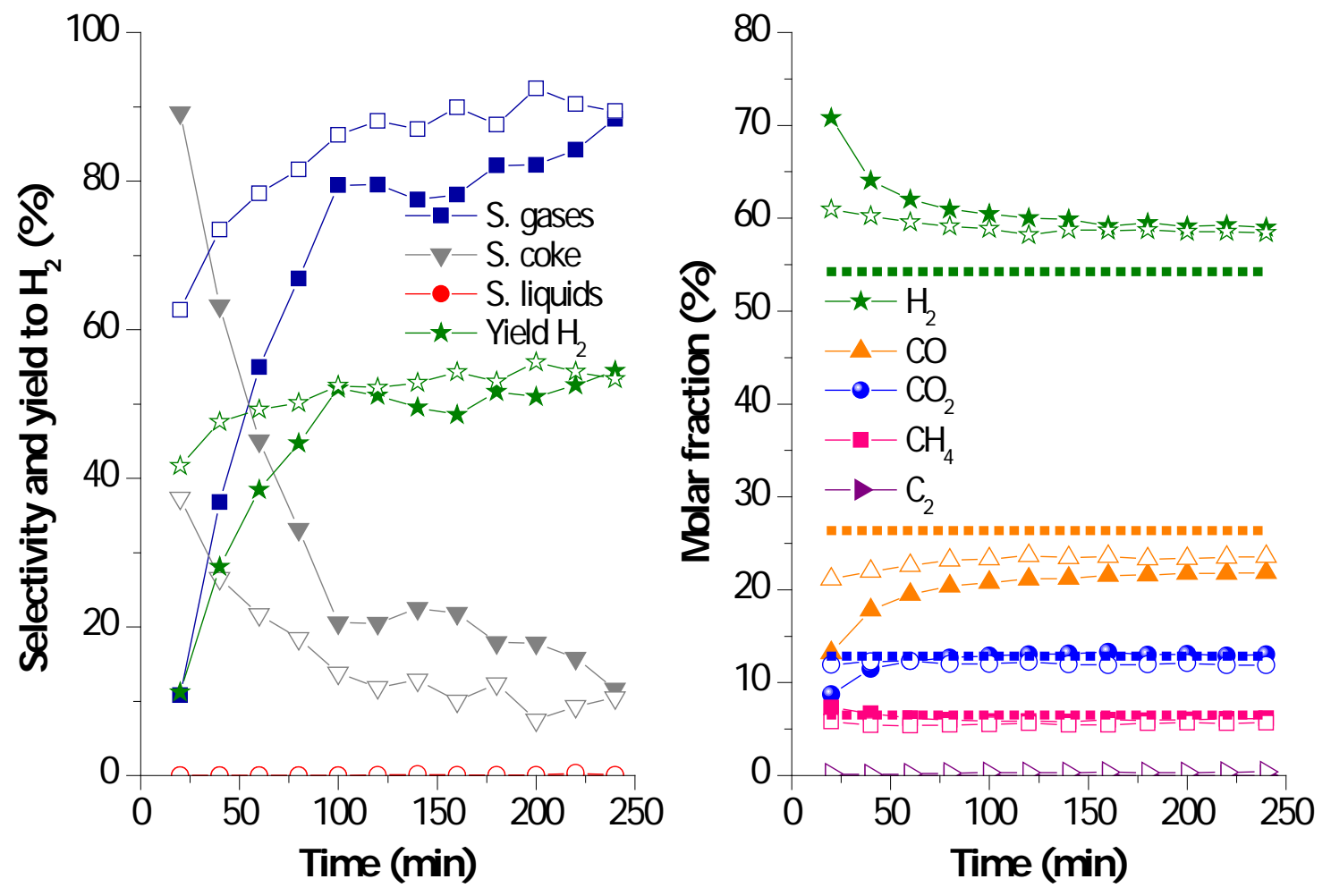
Figure 9. Effect of WGN on the exit gas composition in a TZFBR. Dots: experimental values; lines: thermodynamic equilibrium. $650^{\circ} \mathrm{C} . \mathrm{Q}=91 \mathrm{~cm}^{3}(\mathrm{STP}) / \mathrm{min} . \mathrm{W}=34.5 \mathrm{~g}$.
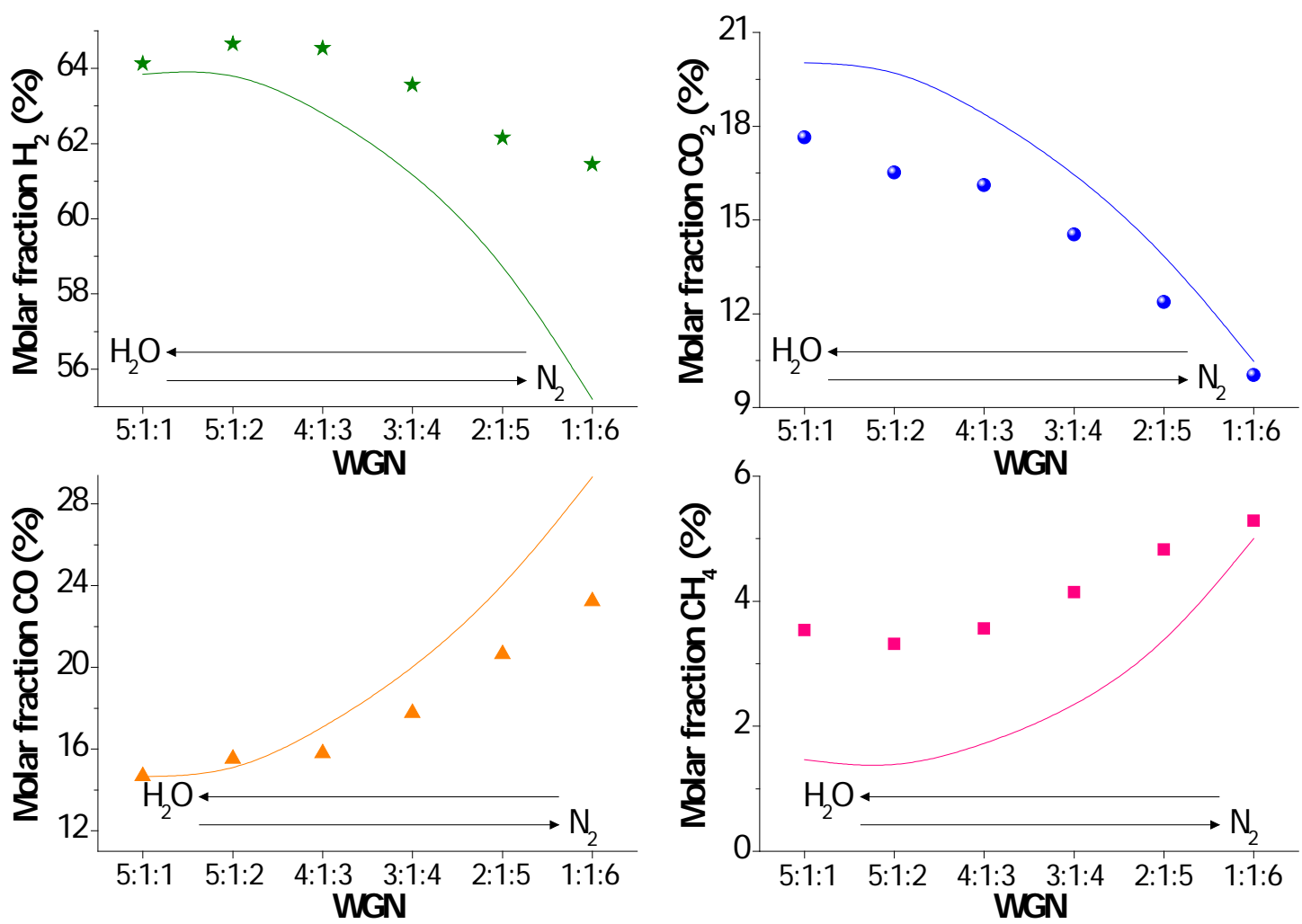
Figure 10. Effect of variable feed flow rate in a TZFBR on the exit gas composition. Parameter: $\mathrm{u}_{\mathrm{r}, \mathrm{u}}$ (ratio of total feed flowrate to minimum fluidization velocity) . Other operating conditions: see Table 6.
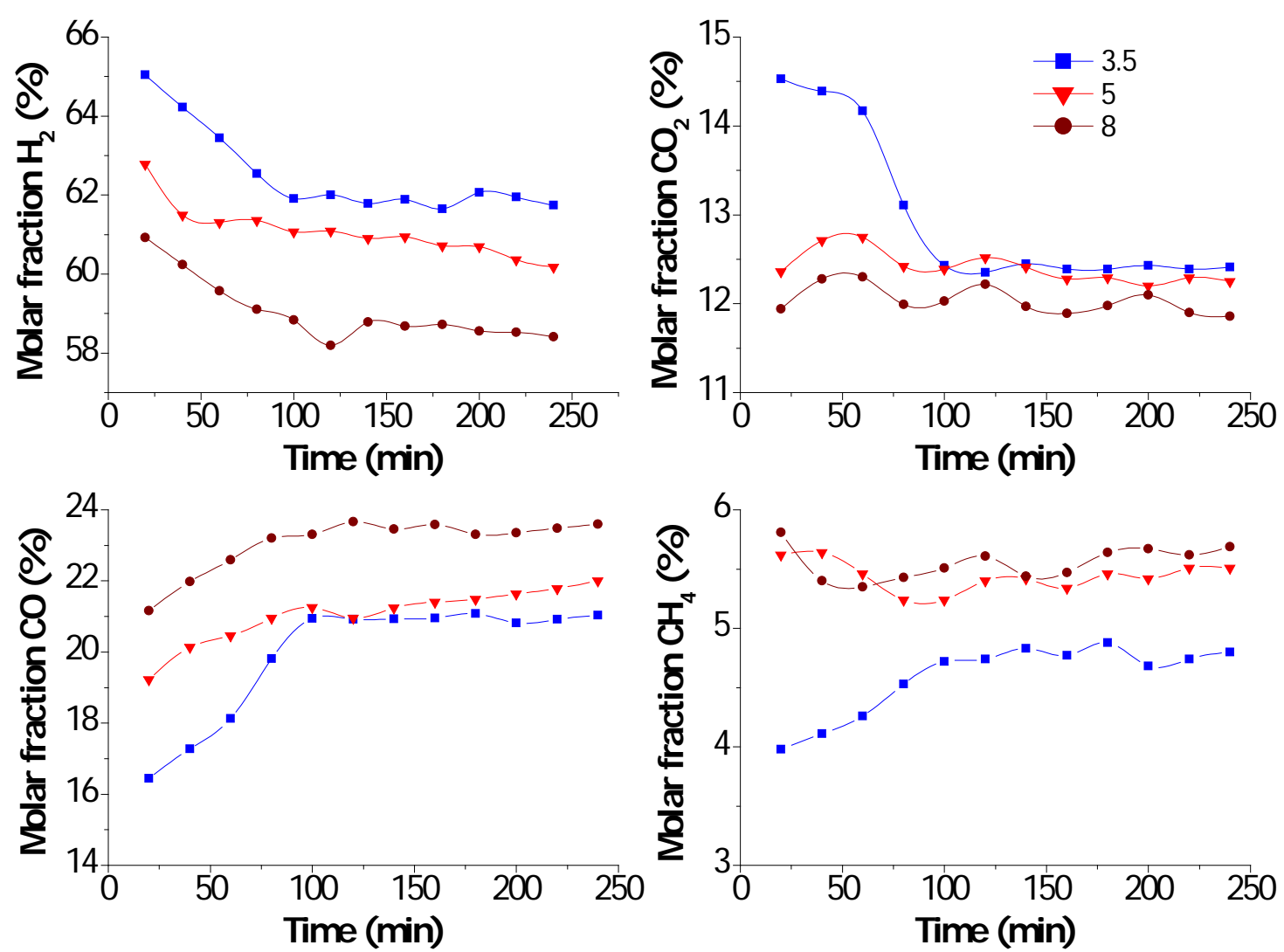
Figure 11. Yield to hydrogen (a) and selectivity to coke (b) as a function of feed flow rate in a TZFBR. Experimental conditions in Table 6.

a)

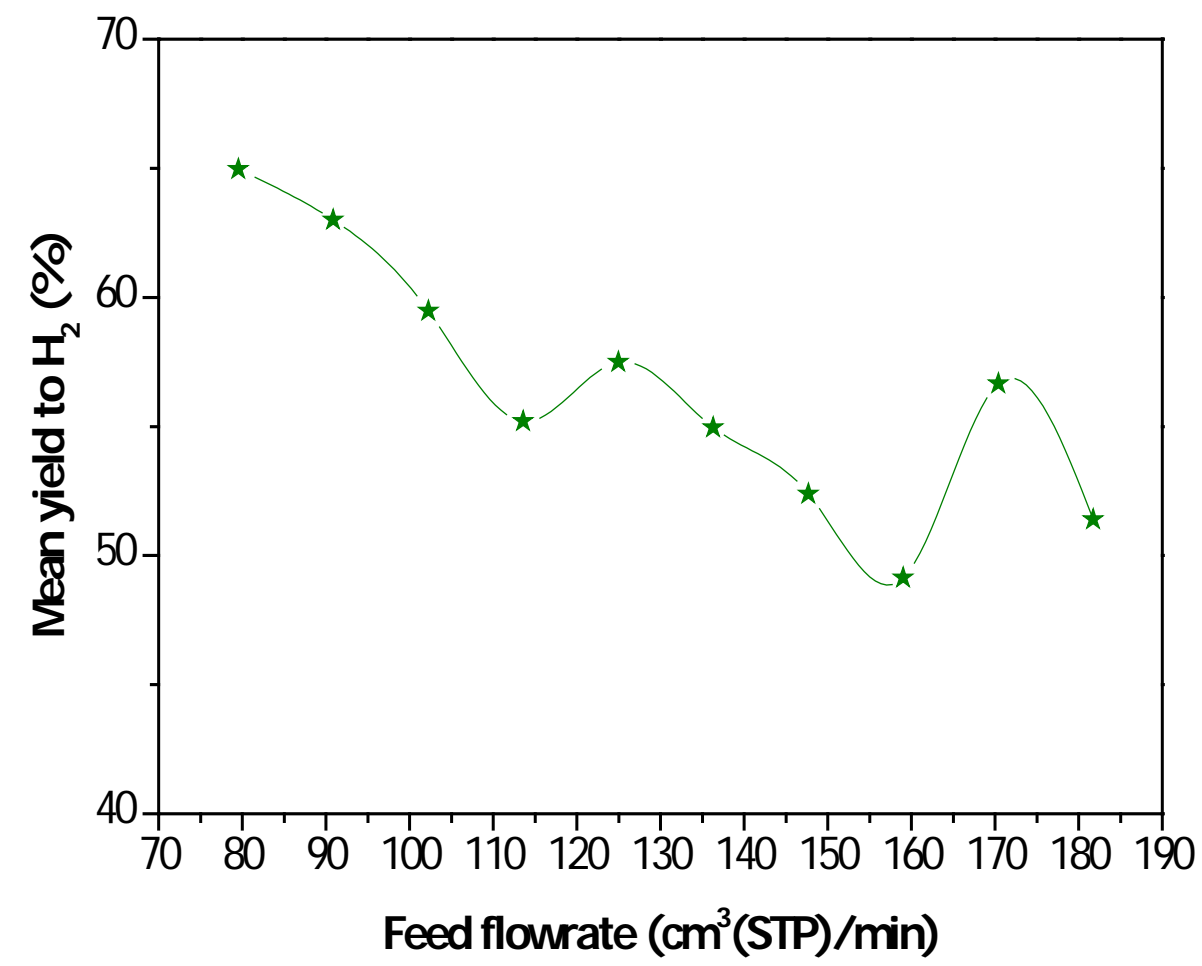

b)

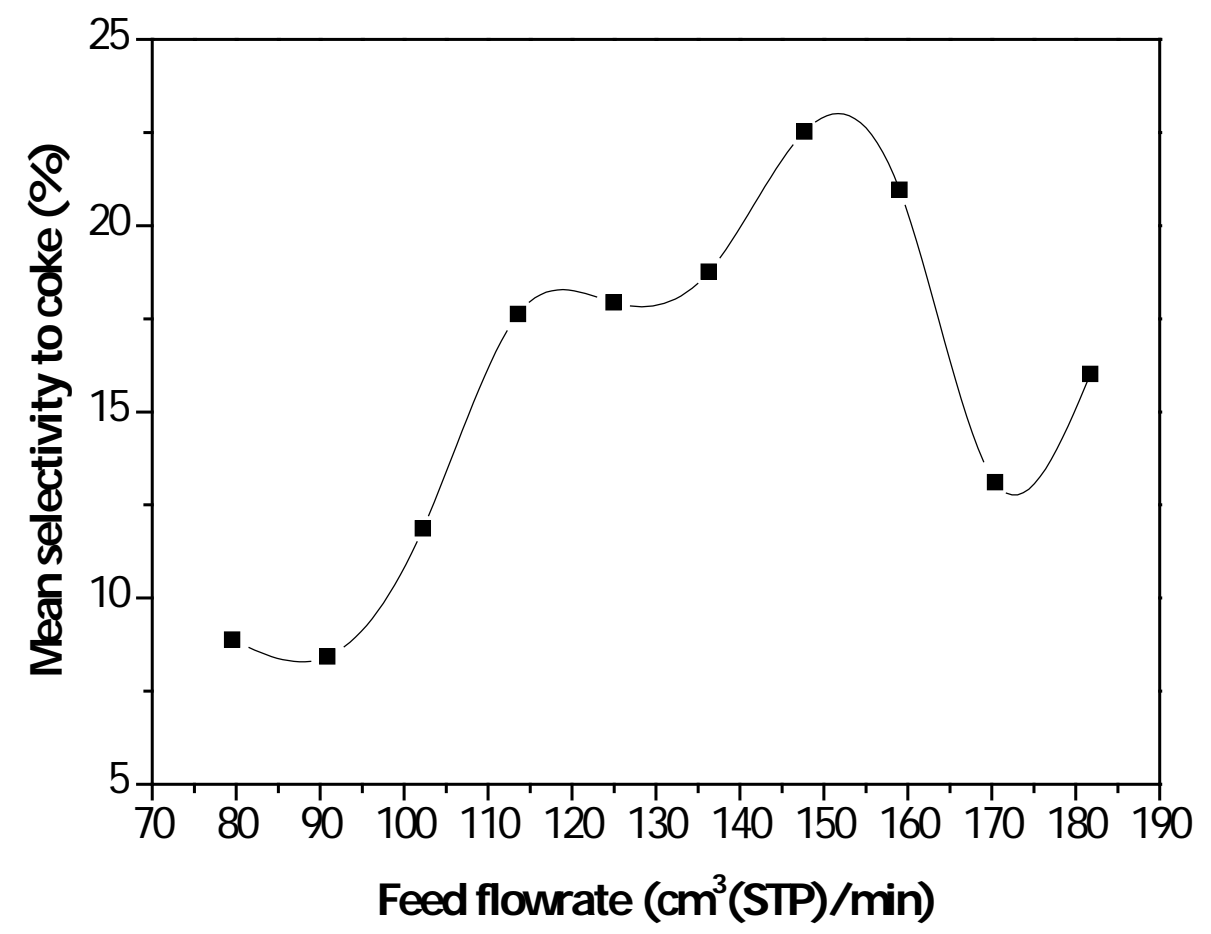


Figure 12. Yield to $\mathrm{C}_{2+}$ as a function of time-on-stream. Parameter: $\mathrm{u}_{\mathrm{r}, \mathrm{u}}$ (experimental conditions in table 6).
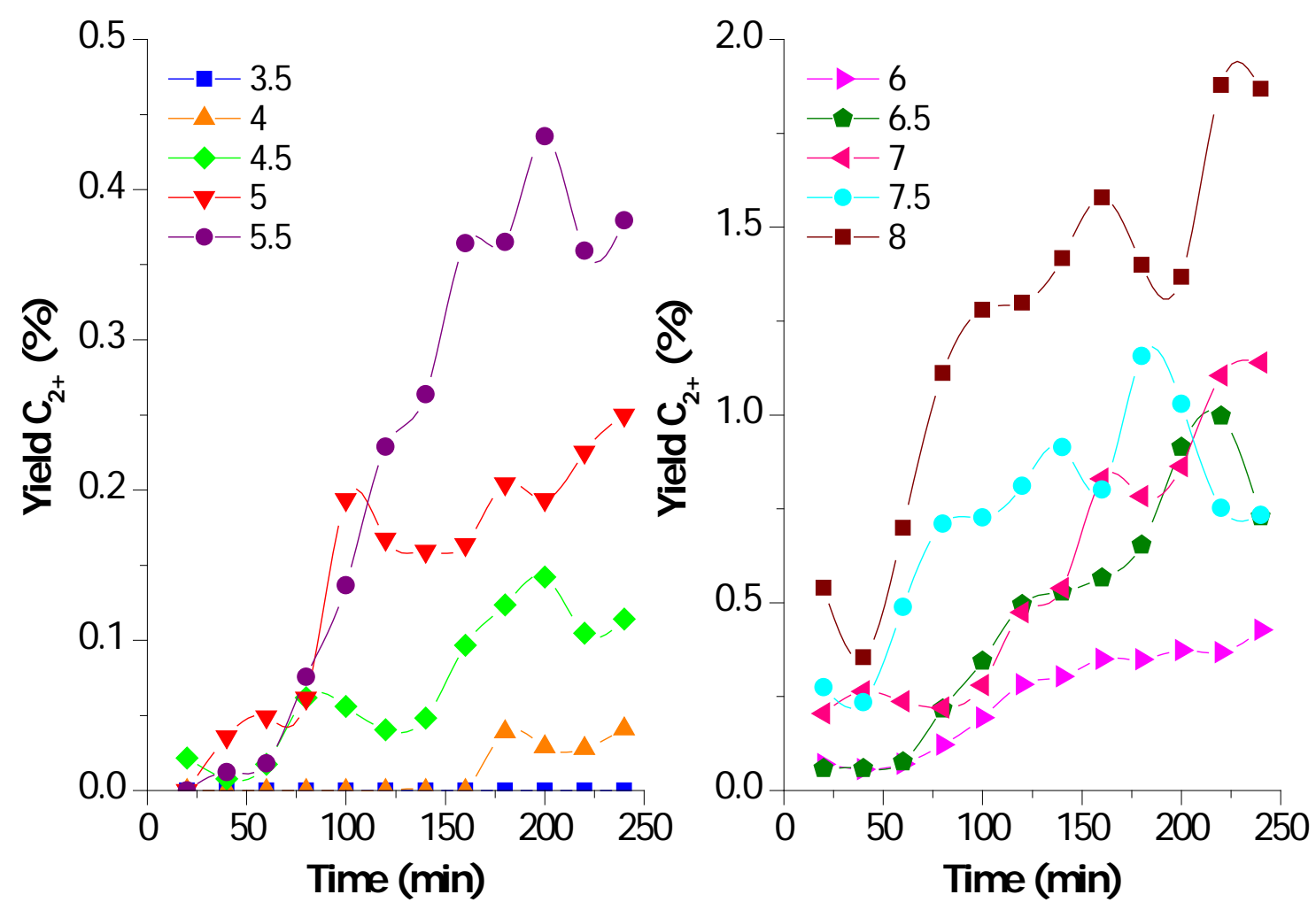
Figure 13. Effect of temperature on the composition of the exit gases in a TZFBR. Operating conditions: $\mathrm{Q}=182 \mathrm{~cm}^{3}(\mathrm{STP}) / \mathrm{min}$; $\mathrm{WGN}=1.25: 1: 1.75$; $\mathrm{W}=35.4 \mathrm{~g}$. Lines: equilibrium (continuous: HYSYS, dotted: FACT [50]).

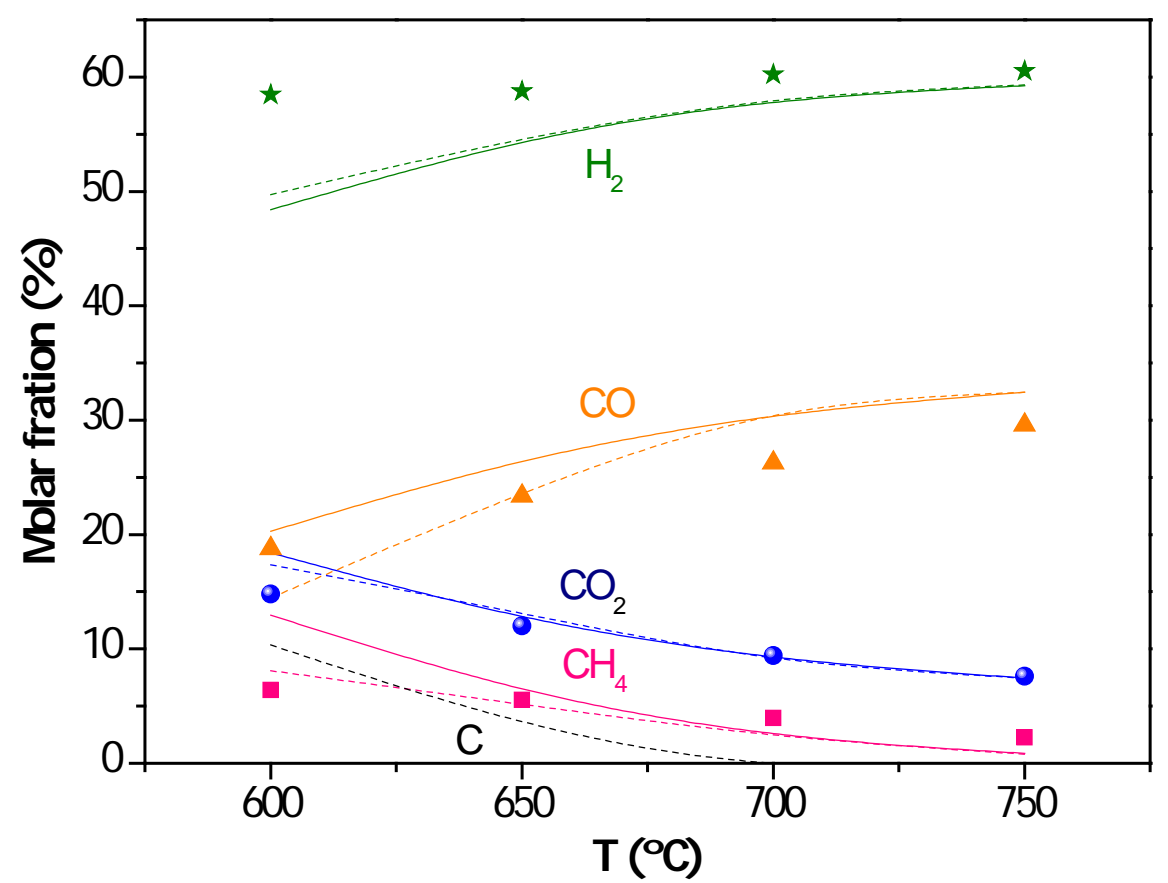


Figure 14. Effect of adding some oxygen in the bottom of a TZFBR. Q=182 $\mathrm{cm}^{3}$ (STP)/min; $\mathrm{W}=35.4 \mathrm{~g}$; Water:glycerol: $\left(\mathrm{N}_{2}+\mathrm{O}_{2}\right)$ molar ratio=1.25:1:1.75. Lines: equilibrium.

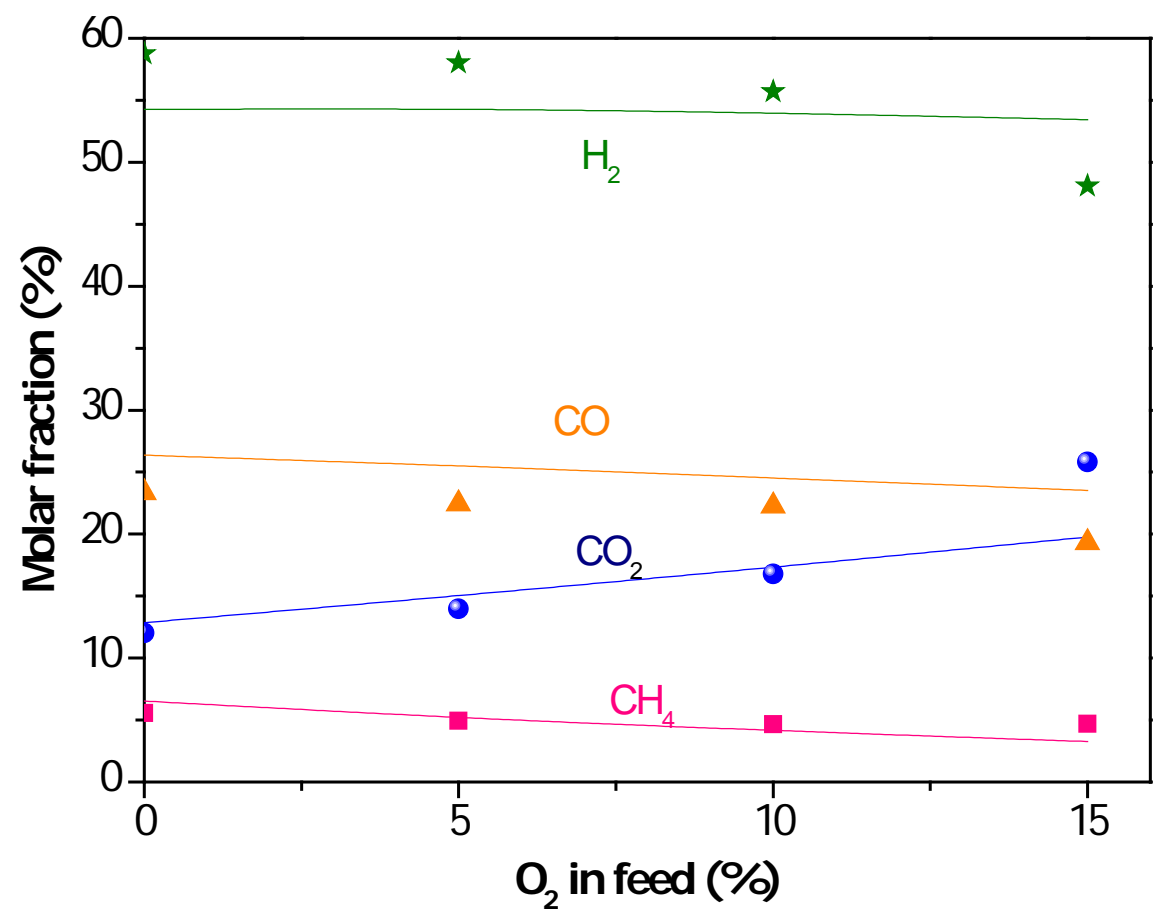


Figure 15. Experiments in a TZFBR feeding $\mathrm{CO}_{2}$ to the bottom of the reactor. Parameter: percentage of $\mathrm{CO}_{2}$ respect to the total feed. Left: selectivity to gaseous products; center: selectivity to coke; left: yield to hydrogen. Water:glycerol: $\left(\mathrm{N}_{2}+\mathrm{CO}_{2}\right)$ molar ratio=1:1:2,; $\mathrm{T}=650^{\circ} \mathrm{C} ; \mathrm{W}=34,5 \mathrm{~g} ; \mathrm{Q}=182 \mathrm{~cm}^{3}(\mathrm{STP}) / \mathrm{min}$.
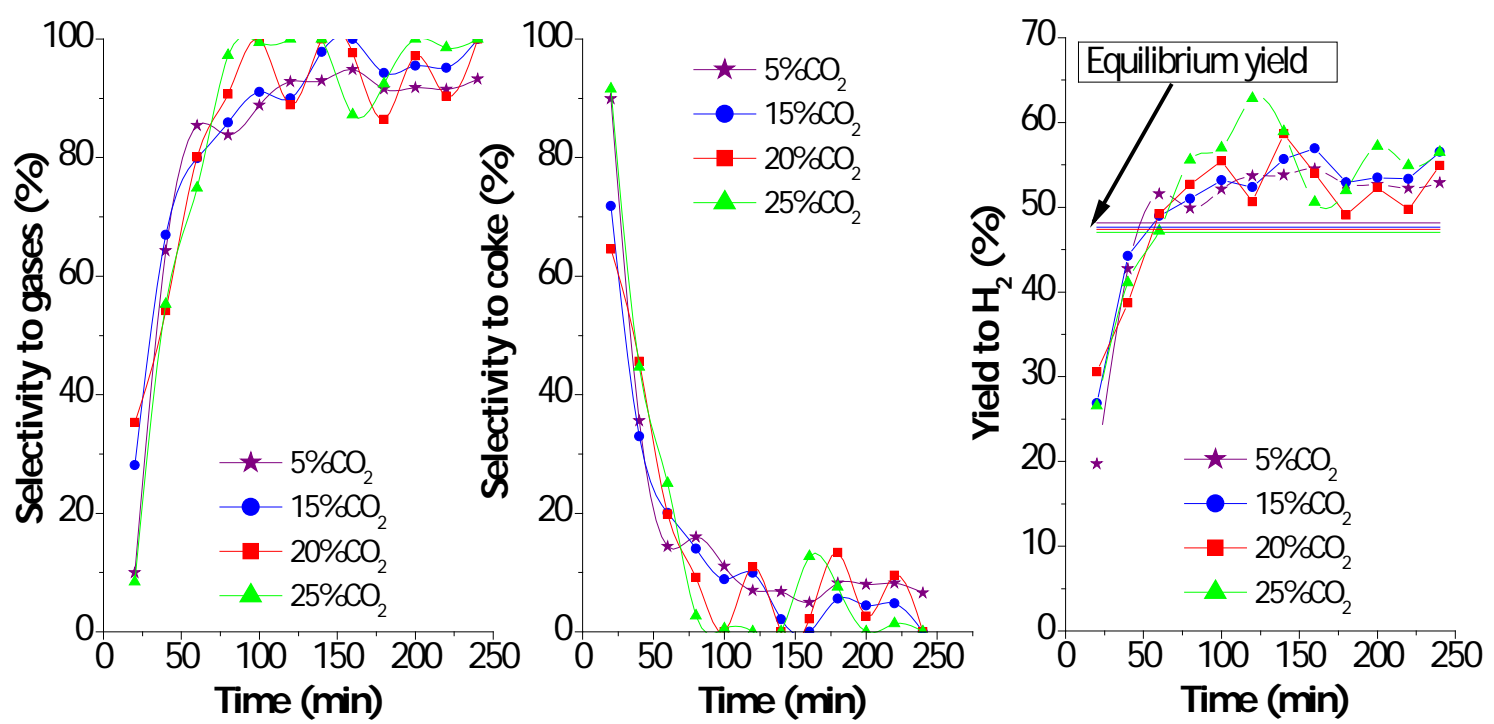
Figure 16. Liquid products obtained in a TZFBR with $\mathrm{CO}_{2}$ as regenerating agent. Experimental conditions as in Figure 15.
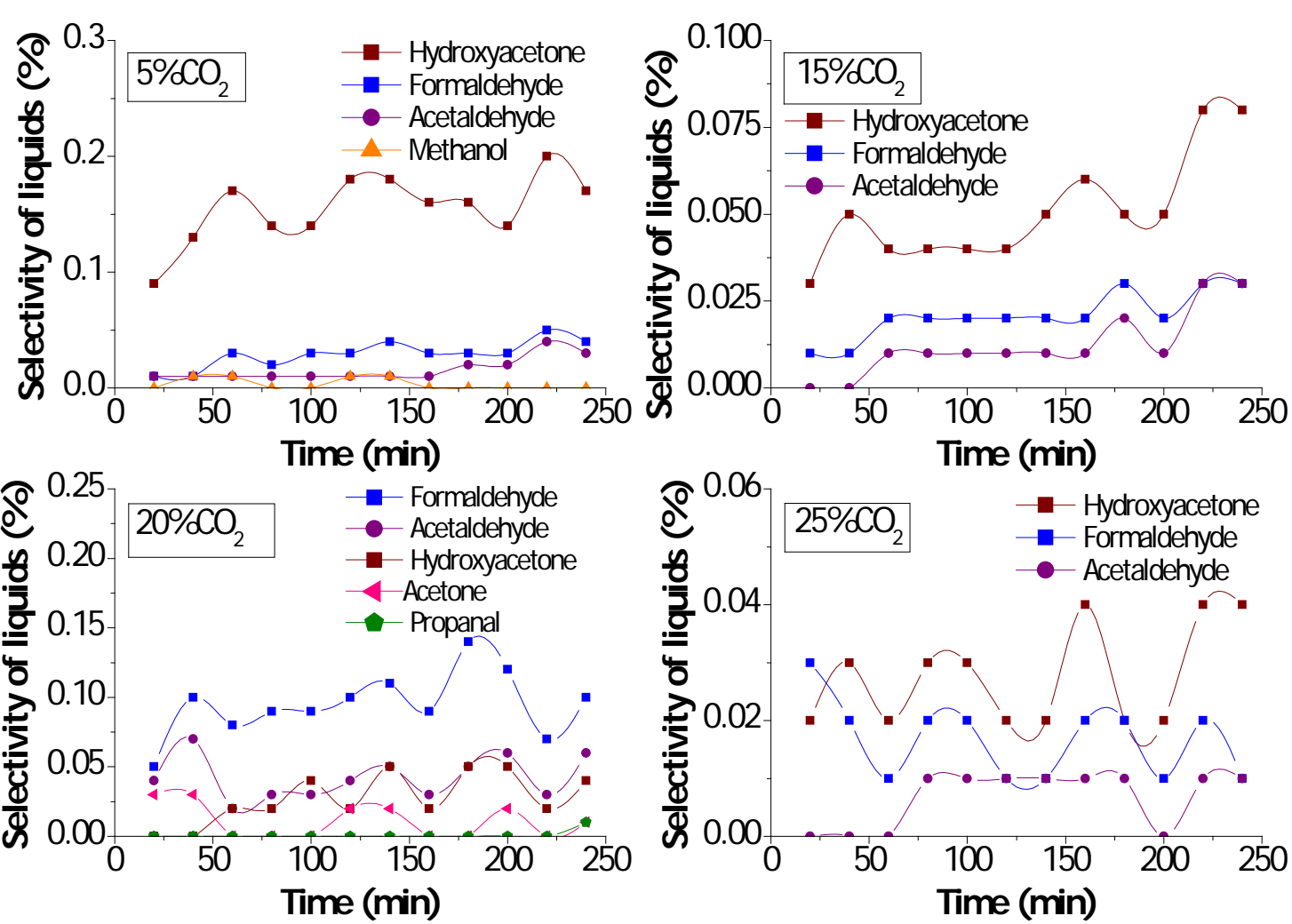
Figure 17. Gas composition in a TZFBR using $\mathrm{CO}_{2}$ as regenerating gas. Experimental conditions as in Figure 15.

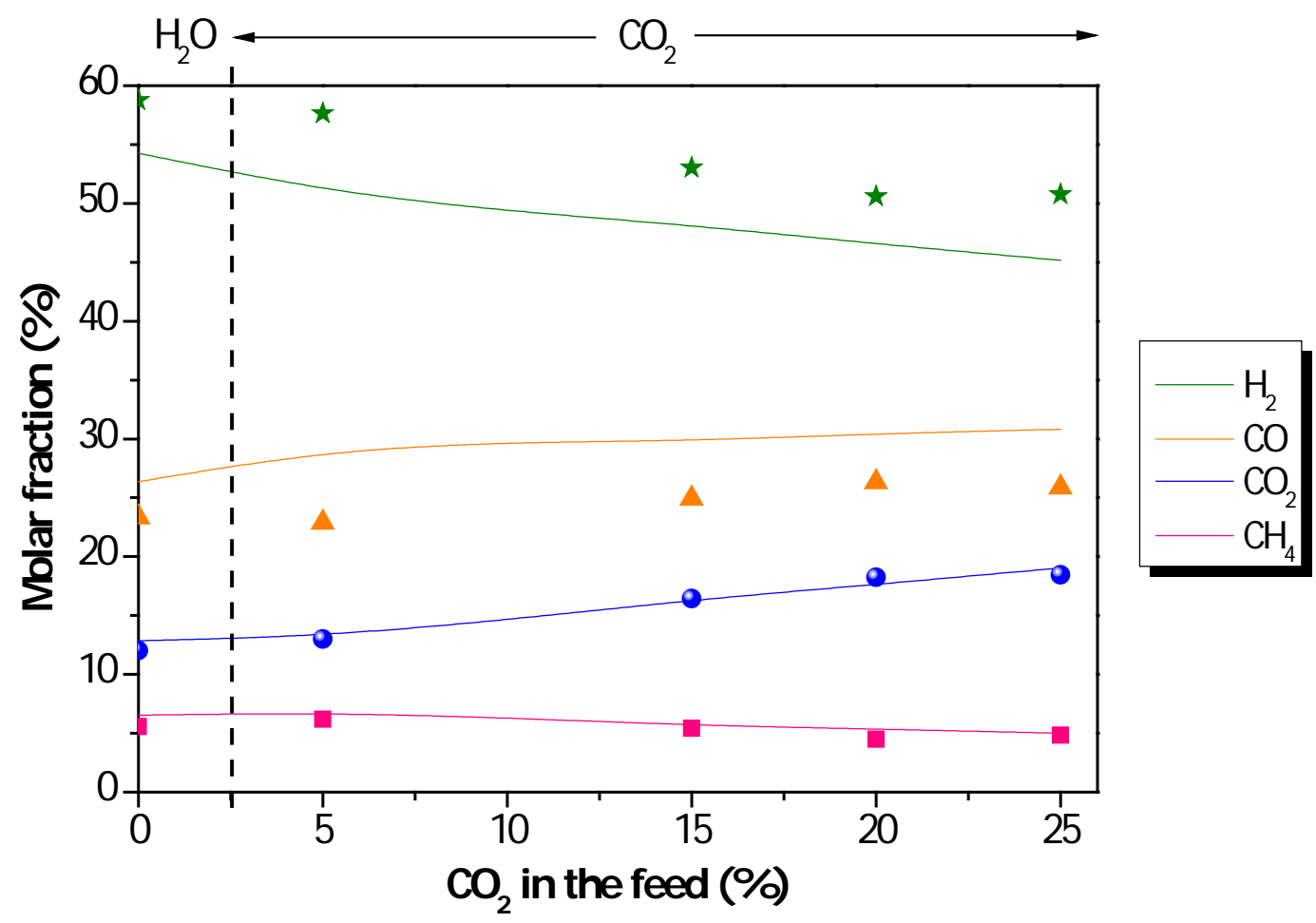


Figure 18. Effect of temperature on the composition of the exit stream when using a TZFBR with $\mathrm{CO}_{2}$ as regenerating gas. Experimental conditions: Molar ratio of water:glycerol: $\mathrm{CO}_{2}: \mathrm{N}_{2}=1: 1: 1: 1$; Other experimental conditions as in Figure 15.

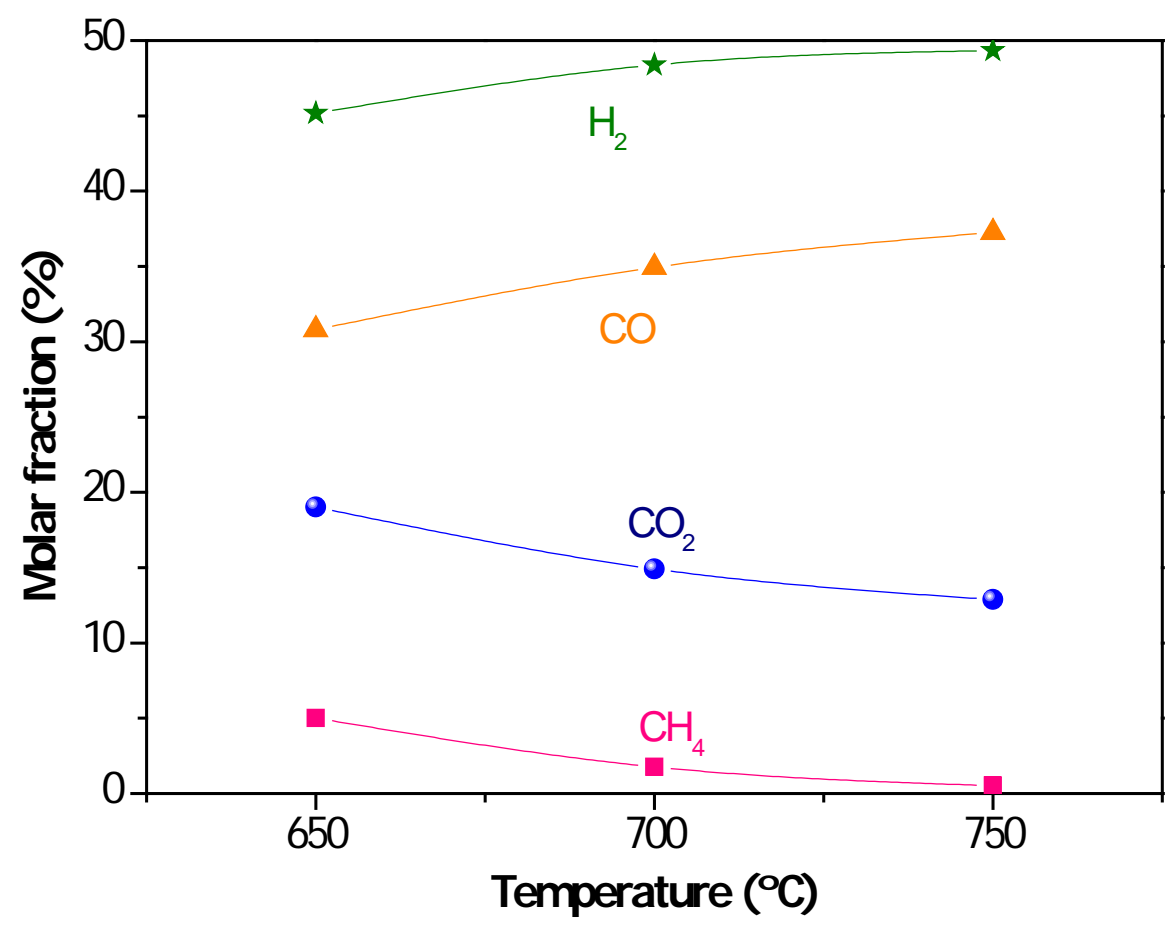

